\title{
The Gametophytes, Archegonia, Fertilization, and Embryo of Sequoia sempervirens.
}

\author{
BY \\ ANSTRUTHER A. LAWSON, Ph.D. \\ Instructor in Botany, Stanford University, California, U.S.A.
}

\section{With Plates I-IV.}

\section{N T ROD UCTION.} LTHOUGH investigations among the Gymnosperms, especially among
the Cycadales and Ginkgoales, have, in the last few years resulted in most important and startling discoveries, this field of research has not received the attention it deserves. The literature on the Coniferales is gradually accumulating and revealing much that is of interest and of importance. These contributions are, however, too fragmentary to deserve the appreciation which they might otherwise receive.

Representatives of every family of the Coniferales have been investigated, especially in regard to the gametophyte generation. Of the numerous types selected by the various investigators many phases in the life-history have been revealed which are of great morphological interest and importance. In spite of the large number of forms that have been worked upon, however, Pinus is the only Conifer in which a connected account of the important events completing the life-cycle has been compiled. The works on the other Conifers are nevertheless of great importance, and although they are at present but disconnected chapters in the life-history, their true value will no doubt be fully appreciated as soon as the missing chapters have been written.

The interesting genus Sequoia is represented by two living species, Sequoia gigantea and Sequoia sempervirens. The former species is confined to very narrow limits in California, while the latter extends along the coast ranges of middle and northern California and for about twelve miles into the State of Oregon. Of the latter species there are at present over one hundred trees growing on the campus of Stanford University. As the majority of these trees are healthy and vigorous, and although young, produce cones every year, and especially as many of them grow in the immediate vicinity of the Botanical Laboratory, excellent opportunity for the daily collections of material was afforded. Taking advantage of these exceptional facilities, I have thought it worth while to work out the morphology of the gametophytes, with the hope of filling in the gaps left

[Annals of Botany, Vo1. XVIII. No. LXIX. January, 1904.] 
by Arnoldi, Shaw, and Strasburger, the only writers who have contributed to our knowledge of the gametophytes of this interesting Conifer.

It is therefore the object of the present work to give a connected account of the events leading to the development of the gametophytes, sexual organs, fertilization, and embryo, thus completing as far as possible the life-history of Sequoia sempervirens.

While the observations recorded by Shaw and Arnoldi are of great interest, they are by no means complete, and as we shall see later, some are even inaccurate.

Shaw (I896) has given a description of how the male and female flowers develop in Sequia sempervirens. When very young he finds that the macrosporangium is about as long as it is broad. The integument at this time consists of an epidermis and two layers of hypodermal cells. The integument develops rapidly and soon comes to be about twice as long as the nucellus. Soon after pollination the upper and inner layers of epidermal cells enlarge and by their elongation finally close the micropyle. By this means the pollen-grains are completely enclosed in a subconical cavity at the apex of the nucellus. Within the nucellus several sporogenous cells now make their appearance. Shaw reports that these cells divide twice, each one giving rise to four macrospores. Upon germination the macrospores develop a number of female prothallia. As the embryo-sacs increase in size they contain several nuclei. The further development of the prothallia was not observed. The archegonia were found to be very numerous and distributed over the upper portion of the prothallium and each one has but a single neck-cell. At the time of pollination each microspore consists of two cells, a large central cell with a large nucleus and a much smaller cell. As the pollen-tube develops the nucleus of the larger cell moves forward and enters the tube. The tube extends down between the nucellus and the integument and as often as not it branches. The further course of the tubes was not followed. Later a number of long suspensors bearing the young embryos on their tips were formed in the endosperm.

Arnoldi (I900) has given a description of the manner of endospermformation in Sequoia sempervirens. According to this description the form of the embryo-sac may vary considerably. When young it consists of a very large central vacuole surrounded by a parietal layer of cytoplasm in which numerous nuclei are found. As the sac develops the parietal layer increases and the protoplasm accumulates in great abundance in the lower end and at the same time the free nuclei divide repeatedly. In the central region a portion of the vacuole remains, and here the cellular endosperm is formed by means of 'Alveolen' as Sokolowa describes for other Conifers, while the remaining endosperm is formed by ordinary free cell-formation. The development of the archegonia is confined to the tissue derived from the 'Alveolen,' so that the prothallium has a distinct generative region. 
In the development of the endosperm in Sequoia, Arnoldi sees a striking similarity to that which occurs in Gnetum.

In the same year (1900) Arnoldi published some observations on the archegonia and pollen-tubes in Sequoia sempervirens. He finds that the archegonia arise from peripheral endosperm-cells and are present in large numbers and may appear singly or in groups. Each archegonium has two neck-cells but none contain a ventral canal cell. The position taken by the pollen-tubes is between the nucellus and the endosperm and they eventually lie opposite the archegonia.

In his more recent work, Arnoldi (I9OI) touches upon fertilization and the development of the embryo. In addition to Sequoia this short paper also discusses these phases in the life-history of Taxodium, Cryptomeria, Cunninghamia, Glyptostrobus, and Sciadopitys. In Sequoia sempervirens, which concerns us more particularly, he finds that the pollen-tube eventually contains two male cells and two free nuclei, of which one is the tube nucleus. At the time of fertilization the male cell becomes elongated or even spirally twisted. The male and female nuclei fuse in the middle of the egg and then move to the base of the archegonium, where the first segmentation-spindle is developed. Following this division two cells are organized, one behind the other. The lower of these divides again so that the embryo now consists of a row of three cells. The lower cell of the first division functions no further and soon becomes disorganized.

On the sporophyte of Sequoia, Peirce (IgOI) has contributed some interesting and important observations on fasciation, albinism and vegetative reproduction.

\section{METHODS.}

There are few groups of plants that offer more difficulties in the way of cytological research than the Coniferales. The structures that are of greatest cytological interest are usually buried deep in the other tissues, thus requiring very careful dissection before being placed in the killing fluids. Then, again, if resin is present, as is usually the case, a rapid penetration of the fluid is impossible.

These and many other difficulties probably account for the fragmentary nature of the work that has been done. A brief statement of the methods adopted in the following work on Sequoia may be useful to others working in this field. The fixing fluids experimented with were as follows :-

I. Flemming's weak solution-

25 c.c. of $I \%$ chromic acid

Io c.c. of $I \%$ acetic acid

Io c.c. of $1 \%$ osmic acid

55 c.c. distilled water. 
2. Flemming's strong solution.

3. Chrom-Acetic mixture.

4. Chromic Acid-I \% sol.

5. Alcohol Acetic.

Of these Flemming's weak solution probably gave the best results although equally satisfactory fixation was generally obtained by the Chrom-Acetic and one per cent Chromic. The Alcohol Acetic solution proved to be a failure.

The fixing fluids were always taken into the field and the material deposited in them immediately. In the very early stages of the ovules and also of the pollen no dissection was necessary. On account of the air present in them these structures had a tendency to float. This difficulty was, however, overcome by sinking the material in the fluid by means of cotton plugs.

In the very early stages the entire ovules were removed and immediately killed without further dissection, but in all the later stages it was found necessary to remove the integument. This, however, was not resorted to until after the pollen-tube had penetrated the nucellus. To insure rapid fixation most of the dissections were made with the material immersed in the fluid. The ovules were removed one by one, placed in a watch-glass containing the fixing reagent and while in the fluid the integument was immediately removed by means of a sharply pointed scalpel and forceps. With a little experience this may be accomplished very rapidly.

The material was allowed to remain in the fixing fluid from ten to twenty-four hours and then washed in running water from four to six hours. Care was now taken in transferring the material to alcohol. For this purpose Schleicher and Schüll's diffusion shells were used. The shells were cut to the height of small beakers and the material placed in the bottom, and $95 \%$ alcohol placed in the beakers. Water was now poured in the shell in sufficient quantity to make the combined solutions about $70 \%$ alcohol. By placing the shell, containing the material and water, in the beaker containing the $95 \%$ alcohol, a gradual diffusion took place which was not sufficiently rapid to cause shrinkage. In two or three hours the material was transferred directly to $95 \%$ alcohol. I found the shells much more convenient than ordinary parchment paper.

In preparation for imbedding the material was thoroughly dehydrated in absolute alcohol. Bergamot oil was used to precede the infiltration of paraffin. After dehydration the material was placed in a mixture of I part absolute alcohol and I part bergamot oil ; then into pure bergamot oil ; then into a mixture of I part Bergamot oil and I part melted paraffin ; and finally into pure paraffin.

Minot's wheel microtome was employed for cutting and the sections varied from $2 \mu$ to $8 \mu$ in thickness according to the detail desired. 
It was found very desirable to use albumen instead of alcohol as a fixative. When the staining was not satisfactory, the sections fixed on the slide with albumen were bleached and restained without trouble. With the alcohol method, however, restaining was impossible, as the sections were invariably washed off the slide. By restaining, many valuable demonstrations were restored.

The triple stain safranin, gentian, and orange G., was found to be the most satisfactory in differentiating the various cell-structures.

\section{The Male Gametophyte.}

The reduction-division of the microspore mother-cell leading to the formation of the tetrads takes place during the first week in December. The first division is rapidly followed by the second, and within a week or ten days after the first division the tetrads have separated and the pollen-grains formed.

The microspores remain within the sporangium at least three weeks before pollination takes place. During this period they become larger, spherical in form, and surround themselves with a hard thick wall. The cytoplasm is very granular and contains a small amount of starch. The nucleus is comparatively small and is always centrally situated (Pl. I, Fig. I). While yet in the sporangium and about a week before pollination the nucleus of the microspore enlarges and divides; so that at the time the pollen is shed there are two nuclei in each grain. Sections made before and after pollination showed a considerable difference in the size of the nuclei, the one being about twice the size of the other. The larger one was centrally situated, while the smaller one was invariably found near the spore wall. The smaller nucleus was surrounded by a sharply differentiated zone of very granular cytoplasm, which suggested the presence of a membrane between the two nuclei as shown in Fig. 2. The chromatin of the smaller nucleus was in the form of small granules closely packed together; it consequently stained more deeply than the larger nucleus, where the meshes of the chromatin network appeared to be much more loosely arranged. A study of the further history of these nuclei has convinced me that the larger nucleus is the so-called tube-nucleus and the smaller one represents the generative cell.

A very careful search was made with the hope of finding a vestige of the vegetative tissue of the gametophyte. One or more vegetative cells have been reported for the Cycads Ginkgo and Pinus, but a most searching examination failed to reveal even a vestige of such a cell or nucleus in Sequoia. I am strongly inclined to believe that the development of these evanescent structures has been entirely suppressed.

Observations of two years indicated that pollination takes place during the first week in January, just about the time the female flowers 
make their appearance. During this time the trees are constantly enveloped in a cloud of pollen, so that it would be almost impossible for any of the exposed ovules to escape the reception of at least a few of the grains. At this time the integument of the ovule is about on a level or a little above the apex of the nucellus, and from four to six pollen-grains are here deposited. The grains remain in this position for three or four weeks without further germination, when the integument grows over them and closes the micropyle in the manner described by Shaw (1 896).

The first indication of the further germination of the pollen-grains was the splitting off of the hard thick wall. (If some ripe grains are examined in water under the microscope, it will be seen that the casting off of the outer wall takes place suddenly and with considerable force, leaving a thin delicate membrane underneath.) The pollen-tubes now push out over the tops of the nucellus, and one or two of them may grow down between the nucellus and the integument, as shown in Fig. 3. Material collected during the first week in March frequently showed the pollen-tubes extending more than halfway down the side of the nucellus. In such cases the tube-nucleus was invariably near the tip of the tube, with the generative nucleus considerably in the rear. Both nuclei were found in the central axis of the tube, suspended in a broad strand of cytoplasm which contained an abundance of starch grains.

While one or two of the tubes may follow the course between the nucellus and the integument, others may penetrate the nucellus immediately at the top, as shown in Fig. 4. The penetration of the tube is accompanied by a breaking down and a probable absorption of the cells of the nucellar tissue through which the tube forces its way. From a study of longitudinal and cross-sections in series it became quite evident that the course taken by the pollen-tubes may vary considerably. At a later stage crosssections of the endosperm showed the tubes in various positions. Usually three or four tubes develop and become functional. In the majority of cases they are found situated between the female prothallium and the remaining tissue of the nucellus. Many were found partially surrounded by endosperm, while others were completely surrounded. In no case was I able to find any evidence of branching of the tube, although Shaw (I896) reports that 'quite as often as not it branches.'

Just about the time the tube penetrates the wall of the nucellus, the generative nucleus, having increased to quite the size of the tube-nucleus, divides. As shown in Fig. 4, there are now three nuclei in the tube, one large one and the two smaller ones. The largest of these, situated nearer the tip of the tube, is no doubt the tube-nucleus, while the other two are the stalk- and body-nuclei. Of these latter two there is a slight difference in size. As the larger one appears to be preparing for further activity, I regard it as the body-nucleus and the smaller one as the stalk- 
nucleus. During the further development of the pollen-tube, the three nuclei remain in close proximity to each other. During these changes the size of the tube-nucleus remained the same, while that of the stalk-nucleus increased slightly. The body-nucleus, however, increased to at least three or four times the size of the stalk-nucleus, as shown in Fig. 5. During its development the body-nucleus surrounds itself with a dense zone of granular cytoplasm. This zone increases until it is about half the diameter of the nucleus in thickness, when it becomes shut off from the rest of the cytoplasm in the tube by a distinct membrane. The tube now contains one large cell and two free nuclei (Fig. 6).

Previous to the formation of the body-cell, the free nuclei lie close together suspended in the same strand of cytoplasm, which contains an abundance of starch. The most of the starch was present in the vicinity of the body-nucleus, and it later becomes confined within the cytoplasm of the body-cell. The stalk-nucleus remains close to the body-cell (Fig. 5), even up to the time the male cells are formed.

The changes resulting in the organization of the body-cell showed considerable variation as to the time of their occurrence. In some cases the mature body-cell was found in material collected early in May, while others were found as late as the middle of June. This irregularity as to the time of the changes was also noticeable in all later changes in the development of the male prothallium, even in the matter of fertilization.

Soon after the body-cell has been fully organized, its nucleus enlarges and prepares for division. By extreme good fortune the spindle of this division was found. As this is the division which results in the formation of the two male cells, it demands a careful examination. It was during the division of the body-cells in Cycas, Zamia, and Ginkgo (Hirase, 1898; Ikeno, I896-8; Webber, 1897-190I) that the centrosome-like bodies known as blepharoplasts were discovered. It was thought probable that a vestige of such an organ might be found in Sequoia, but an examination of the cytoplasm surrounding the spindle failed to reveal a trace of any body that might be interpreted as a blepharoplast. It must be remembered, however, that the blepharoplasts are only concerned with the development of the cilia, and as these latter structures have never been found in connexion with the male cells in Conifers, it is not surprising that the organs responsible for their formation should also be missing. Fig. 7 shows the spindle dividing the body-nucleus with the daughter-nuclei at the poles. The formation of the cell-plate that separates the nuclei and divides the body-cell into two was not actually observed. But an examination of Fig. 7 where the connective fibrils curve out laterally, and of Fig. 8 where the two daughter-cells are lying side by side, makes it obvious that the cell-plate is developed in the usual way. After the wall separating the male cells has been formed, the latter remain close together for some 
time, and a section of the two together has the outline of an ellipse that has been cut in half. They are rounded on one side and flat on the other. They are of equal size, and, as we shall see later, are both functional. Just before the male cells separate from each other, the nucleus in each has increased to about twice its original size. The chromatin is in the form of a network which contains a large irregularly shaped nucleolus.

At the time of fertilization the male cells become almost spherical, and are perfectly similar in regard to their size and structure. Arnoldi (I9OI) has reported that the male cells may become elongated, and he figures one that has a spirally twisted form. I was unable to find such conditions, and feel confident that they are abnormal or due to shrinkage by poor fixation. In all the cases I have examined the male cell was spherical, and, as we shall see later, its spherical form may persist for some time after its nucleus has been injected into the egg.

As we shall point out later, under the head of fertilization, only the nucleus of the male cell enters the archegonium, the rest of the male cell remaining outside in the pollen-tube. The nucleus is first liberated and, with but a small film of protoplasm surrounding it, passes between the neck-cells of the archegonium and immediately fuses with the egg-nucleus. In all other Gymnosperms in which observations have been recorded, at least one male cell enters the archegonium, so that in this respect the spermatogenesis of Sequoia is unique. According to the following diagram, Coulter and Chamberlain have compared the spermatogenesis of the Cycads with that of Isoëtes.

Isoëtes.

Cycads.

Sequoia sempervirens.
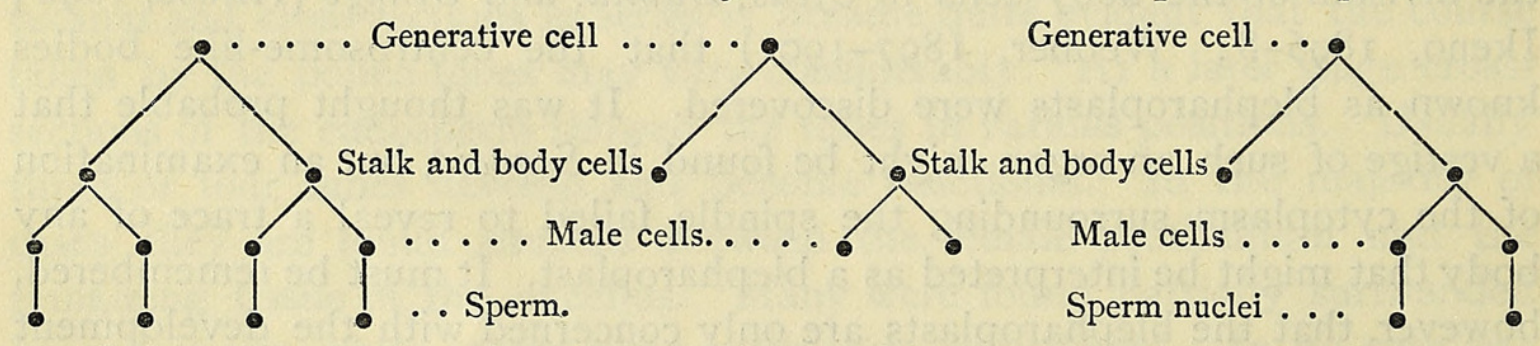

It will be observed that the male gametophyte is complete with the organization of the male cells, and this is true for all other gymnosperms where spermatogenesis has been worked out. If, however, we construct a similar diagram for Sequoia, the additional step of the discharge of the male cell-nucleus suggests more strongly the spermatogenesis of the Pteridophytes than even that of the Cycads, although the male cells of the later are ciliated. 


\section{The Female Gametophyte.}

Shaw (1896) has given an accurate account of the development of the macrosporangium and the integument, but has, however, given a very meagre description of the sporogenous cells and the macrospores. There may be as many as five or six macrospore mother-cells organized from the hypodermal cells of the sporangium. Many preparations were made of this stage in the development of the sporangium, and a special study was made of the mother-cells as soon as they became differentiated from the surrounding sterile cells. They first become recognized as mother-cells by their large deeply staining nuclei. In the beginning they are not much larger than the other hypodermal cells, but they very soon enlarge, and their cytoplasm becomes very dense and granular and stains very readily with orange G. They are further characterized by the absence of large vacuoles. They are situated just about the centre of the sporangium; about five or six layers of cells lying between the uppermost of them and the epidermis at the apex. A careful study was made of the number of mother-cells formed, and there seems to be a slight variation in this respect. Six was the largest number found. In all the sporangia studied five or six was the prevailing number, but in no case were fewer than four found.

Shaw (I 895) has reported that these sporogenous cells divide twice, each cell giving rise to four spores. As there are nearly always five or six of these sporogenous cells developed, and if each one gave rise to four spores, this would result in the formation of twenty or twenty-four macrospores. We shall show later that no such large number of macrospores were formed, but that, on the contrary, ten or twelve were the prevailing numbers met with. Owing to Shaw's statement, it was thought probable that some of the sporogenous cells had failed to divide and that others had divided twice. Accordingly a very vigorous search was made for the stages showing a second division. Although the spindles of the first division were found frequently, some with the chromosomes at the equator of the spindle (Fig. Io), and others with the daughter-nuclei formed, in no case was there any evidence of four spores having been formed from a single mother-cell. From these observations I feel tolerably certain that the five or six sporogenous cells (Fig. 9) differentiated from the hypodermal cells of the sporangium are the macrospore mother-cells, and after dividing twice give rise to the ten or twelve macrospores; one cell of the second division fails to develop.

Soon after their organization, about the first of March, the mother-cells divide, each producing two macrospores. As this division of the mothercell is the reduction-division, which marks the beginning of the gametophyte, the character and number of the chromosomes demanded considerable attention. As far as the writer is aware, the reduction of the chromosomes 
in the division of the macrospore mother-cells has never been actually observed in any of the Conifers. It was hoped that, as the spindles were found, some light might be thrown upon this most important step in the life-history of Sequoia, but after the examination of the chromatin, all such hope was lost. The spindle of the reduction-division was found in several preparations, but the chromosomes were too many to allow of an accurate estimate of their number. To add to the difficulty, the chromosomes were in the form of large $\mathrm{V}$-shaped structures. The arms of the $\mathrm{V}$ were very long, and when at the equator they extended almost to the poles of the spindle. It also invariably happened that several of the chromosomes overlapped their neighbours, making it almost impossible to observe the method of splitting and separation. It was interesting to note, however, that as the daughter-chromosomes approached the poles of the spindle they were very much smaller than the mother-chromosomes at the equator; this condition, however, was also observed in the divisions during the formation of the prothallium and also in the young sporophyte. Although the actual reduction could not be observed in the division of the macrospore mother-cell, we shall point out later that the number of chromosomes in the prothallium and in the development of the archegonium is obviously half that in the embryo. Reduction-spindles are shown in Fig. Io.

Soon after the macrospores are formed, they surround themselves with distinct walls and almost immediately begin to germinate. The germination is first noticeable by a slight increase in the size of all of the spores. This increase in size is always accompanied by a division of the nucleus, so that each of the ten or twelve germinating spores or female prothallia has two free nuclei in its cytoplasm. Their further growth is apparently at the expense of the sterile tissue in which they lie imbedded. The cells in this tissue, in contact with the young growing prothallia, show every sign of disorganization; the nuclei appearing as homogeneous deeply staining masses lying in the distorted and more or less fragmented cells. At this stage (Fig. II) there are about eight or ten layers of sterile cells between the uppermost macrospore and the apex of the sporangium. The majority of the young prothallia show no further development after the first nuclear division, but two or three of them continue to elongate, and their increase in length is always directed toward the chalaza. Such a condition is shown in Fig. II. Here eight young prothallia are represented, five of which have grown but very little, while the remaining three are many times the size of the original spores. The smaller prothallia function no farther, and are probably absorbed by the growth of the larger ones. Of the two or three larger prothallia represented at this stage, and which continue their growth down through the nucellar tissue, one grows more rapidly than the others, and for convenience we will speak of it as the primary prothallium. The one or two remaining prothallia persist in their further development, 
and since (as we shall point out later) they have a considerable influence on the ultimate form of the primary prothallium, we will designate them as the secondary prothallia.

The growth of the primary and secondary prothallia is always accompanied by a rapid division of their free nuclei. Stages were found showing two, four, eight, sixteen, and thirty-two free nuclei. It was too difficult to count the numbers greater than this in sections, but this was sufficient to indicate that there is a regular and successive division of all the free nuclei, at least in these early stages. By the time the prothallia have reached the two or four nuclei stage the sporangium has increased to over twice its length. As Shaw (1895) has pointed out, the growth resulting from the elongation of the nucellus is very much greater in the region between the spores and the chalaza.

At the time when there are eight or sixteen nuclei in the prothallium, as shown in Fig. I2, there is a layer of cytoplasm lining the walls, and there may be several vacuoles separated by strands of cytoplasm which contain many starch-granules. The nuclei at this time are suspended in a broad strand of cytoplasm which runs the length of the young prothallium and are usually arranged in a row, as shown in Fig. I2.

The further increase in the size of the primary prothallium is always accompanied by an increase in the size of the vacuoles as well as an increase in the number of free nuclei. Although the primary prothallium is at this time somewhat larger than the secondary, the two present much the same condition. From now on, however, the rate of their development is very different. The development of the primary prothallium proceeds very rapidly, and is followed very slowly by that of the secondary, which, as we shall see later, never produces true cellular prothallial tissue.

The initial stages in the development of the prothallium agree in general with the conditions found in Taxus by Jäger (I 899) and Campbell (1902), and in Pinus by Coulter and Chamberlain (I901), with this difference, that more than one prothallium in Sequoia reaches an advanced stage of development. The following events, however, which lead to the formation of the cellular prothallium differ in many interesting respects from any of the Conifers in which the endosperm-formation has been worked out. As Arnoldi (1899-1900) has pointed out, the events are strikingly similar to those found by Lotsy (I899) in the formation of the endosperm in Gnetum.

As the vacuoles in the primary prothallium grow, they eventually fuse together to form an enormous single vacuole which forces the cytoplasm and the nuclei to the walls. As represented in Fig. I3, the prothallium now consists of a large central vacuole, surrounded by a comparatively thin layer of cytoplasm in which a large number of free nuclei are distributed along the wall which surrounds the whole structure. The amount of cytoplasm 
now increases considerably, and free nuclear division proceeds at a rapid rate. The cytoplasm and nuclei, as they increase, accumulate in greater abundance at the lower end, and as this accumulation goes on, the large vacuole becomes correspondingly smaller and is confined to the upper end of the prothallium. Up to this time the shape of the prothallium has been more or less irregular in outline, the upper region remaining more or less constricted as compared with the broad middle and lower portions, and there has been no trace whatever of any cell-plate formation between the free nuclei. A portion of the prothallium in this condition is shown in Fig. I4.

In his recent work on the formation of the endosperm in Sequoia sempervirens, Arnoldi (I900) finds that as the parietal layer of cytoplasm thickens it accumulates in great abundance at the lower end of the prothallium. Free cell-formation now proceeds in the lower and upper regions, but in the region surrounding the vacuole, structures ('Alveolen') similar to those described by Mlle. Sokolowa (I89I) in the formation of the endosperm of other Conifers are organized. The 'Alveolen' ultimately give rise to ordinary cellular tissue. He also reports that the archegonia are developed only in the tissue derived from the 'Alveolen.'

My own observations on the thickening of the parietal layer and the accumulation of the cytoplasm and nuclei in the lower and upper regions agree very closely with those of Arnoldi. I was, however, unable to observe the formation of 'Alveolen' as he describes. As the long narrow vacuole continues to decrease in size, the cells surrounding it become larger. And these are no doubt the structures Arnoldi interprets as 'Alveolen.' As we shall point out later, the archegonial initials are not confined to this region.

A careful study of this stage in the development of the prothallium has convinced me that the final division of all the free nuclei which immediately precedes cell-plate formation is nearly simultaneous. In a single section over two hundred and fifty mitotic figures were counted. Many of these spindles showed the chromosomes at the equator. Some of them, even at the lower and the upper regions, showed the daughter-nuclei formed with the connective fibrils between them (Fig. I5). The nuclei in the vicinity of the vacuole divided in the same way and at the same time as the other nuclei, and I therefore could not confirm Arnoldi's observations on the formation of 'Alveolen' in this region. That this was the final division of the free nuclei was shown quite conclusively by the fact that cell-plate formation had already begun between some of the daughternuclei in various regions of the prothallium.

With so many nuclei undergoing division just about the same time they presented every possible phase of mitosis. Some of the nuclei were enlarging and just preparing to divide, many showed the chromosomes at the equator, others showed the chromosomes on the way to the poles, others again 
showed the daughter-nuclei well organized, with the kinoplasmic fibrils stretching between them. As near as could be estimated, the number of chromosomes appeared to be sixteen. These various stages of the dividing nuclei had an influence upon the rate at which the cell-plates were formed, and consequently the various regions of the prothallium showed all stages in the development of the plates.

While the daughter-nuclei resulting from this division are being organized, the continuous fibrils of the spindle persist and increase in number; the result is that each daughter-nucleus is surrounded by a system of kinoplasmic radiations. These radiating fibrils not only join the sisternuclei but they connect with the fibrils radiating from the other neighbouring nuclei. The result is that certain regions of the prothallium show large numbers of nuclei all joined together by systems of radiating fibrils, as shown in Fig. 15. Each nucleus at this time is enveloped in a dense granular zone of cytoplasm, from which the system of kinoplasmic fibrils radiates. The radiations show all the characters of ordinary spindlefibrils, and they apparently have the same origin, that is, they are differentiated out of the cytoplasm. The first indication of the plate appears in the form of small granules or thickenings on the fibrils. These thickenings occur about midway between the nuclei, and as they increase in size the fibrils become less numerous in the vicinity of the nuclei. This would suggest that the fibrils were transformed into plate-forming substance, in much the same way as Timberlake (I899) has indicated. As illustrated in Fig. 16, the thickenings occur on all the fibrils stretching between the nuclei, so that each nucleus becomes completely boxed in by the developing plates. Different regions of the prothallium showed various stages in the formation of the plates. In a single section we may have conditions represented in Fig. 15 and Fig. 16 , or where the daughter-nuclei are just being organized.

In the upper portion of the prothallium some of the cells may be very large and elongated. These are no doubt the structures which Arnoldi (I9OI) has described as 'Alveolen.' I find, however, that the archegonial initials may develop much below this region, and I therefore cannot endorse Arnoldi's view that there is a distinct generative tissue in the prothallium of Sequoia sempervirens.

It is interesting to note that Arnoldi has reported a very different method of endosperm-formation in Sequoia gigantea. Here the entire endosperm is formed in much the same way as in other Conifers described by Sokolowa (189I), that is, by means of 'Alveolen.' When such great difference exists between two species of the same genus, it tends to eliminate the endosperm-formation as a means of establishing relationships among the Coniferales.

During the development of the primary prothallium as described 


\section{Lawson.-The Gametophytes, Archegonia, Fertilization, and}

above, one or two of the secondary prothallia have continued their growth, but at a much slower rate. Previous to the formation of the cell-plates, it is difficult to distinguish between the primary and the secondary prothallia, but after free cell-formation has ceased in the primary prothallium, the form of the secondary prothallium becomes well defined. Its course is long and tortuous, and in many cases winding in and out through the tissue of the primary prothallium, as illustrated in Fig. 18. Its shape is greatly modified, as its growth is limited to the spaces left by the more rapidly growing primary prothallium. Instead of having a single large vacuole and a parietal layer of cytoplasm, several long narrow winding vacuoles are present, separated by strands of cytoplasm. In several cases the spindles were found, showing that nuclear-division is carried on in the same manner as in the primary prothallium. In no case, however, was there any trace of cell-plate formation observed, so that I am inclined to believe that the secondary prothallia never develop sufficiently to produce cellular prothallial tissue.

A very interesting relationship between the primary and secondary prothallia was noticed, which no doubt explains the sluggish development of the latter. After the cell-plates were formed in the primary prothallium, the parietal protoplasm of the secondary prothallium clings very closely to the cells of the former. These cells grow out into the free protoplasm and evidently act as absorbing organs. This intimate relationship is shown in Fig. 19. Here the newly formed cells are seen projecting into the protoplasm of the secondary prothallium in a dovetail fashion. The nuclei of these cells are very much larger than the others, and have the appearance of being engaged in very active metabolism. There is no doubt that these projecting cells absorb the protoplasmic substance of the secondary prothallium, and thus retard its development.

The primary prothallium of Sequoia takes just about three months to mature. The macrospores are formed during the first week in March, and the first archegonial initials were observed in material collected June 8 . At this latter date the nucellar tissue had been almost completely absorbed, little more than the epidermal layer of cells remaining. Within the integument we now have a most confusing complex of structures, for in addition to the primary cellular prothallium there are usually present one or two secondary prothallia in an advanced stage of development and three or four pollen-tubes.

\section{The Archegonia.}

Very soon after the nuclei of the endosperm have been shut off from each other by the cell-plates, and after true cellular prothallial tissue has been organized, certain cells in the upper half of the prothallium become differentiated into the archegonial initials. These cells are quite numerous, and occupy a position not at the periphery, but near the central axis of the 
prothallium. In cross-sections of this region, as shown in Fig. 26, they may be easily distinguished from the surrounding vegetative cells. When first differentiated, their distinguishing characters are their large size, highly granular cytoplasm, which stains readily with orange G., and each one has a large, centrally situated, deeply staining nucleus. When first distinguishable, the archegonial initials are not much larger than the ordinary vegetative cells by which they are surrounded. They rapidly increase in size, however, and are soon several times their original dimensions. As they do not all enlarge simultaneously, they present various shapes and sizes, and sections very frequently showed the matured archegonia and the young initials in the same plane. As the initial grows in size, the cytoplasm appears more conspicuously granular, and the nucleus becomes much larger as it prepares for the division which cuts off the primary neck-cell. This first mitosis of the archegonial initial takes place during the latter part of June. Sections of material collected June 25 showed an abundance of the various stages of the spindle. Fig. 20 shows one of them with the chromosomes on the way to the poles. These various stages of mitosis afforded an excellent opportunity of confirming the observation made during the endosperm-formation, that the number of chromosomes in the gametophyte is half that of the sporophyte. A comparison of Fig. 20, which represents the last spindle but one in the life-history of the gametophyte, with Fig. 32, which represents the first mitosis in the history of the sporophyte, shows without much question the difference in the number of the chromosomes in the two generations.

In addition to the archegonial initials numerous jacket-cells are also differentiated. These are distributed very irregularly among the archegonia. Some archegonia may be almost surrounded by the jacket-cells, while others may be completely devoid of them. In the early stages of differentiation it is impossible to distinguish between the jacket-cells and the archegonial initials. They are structurally identical in regard to their cytoplasm and nuclei. This fact, accompanied with their irregular distribution over the prothallium, suggests very strongly that the jacket-cells are archegonial initials which have become sterile.

As soon as the first mitosis is completed, the archegonial initial is divided into two by a distinct cell-wall. The two cells thus formed are the central cell and the primary neck-cell. The central cell now grows very rapidly, and, as shown in Fig. 2I, comes to be many times the size of the primary neck-cell. It was noticeable that the elongation of the central cell always took place in the direction of the neck-cell, so that the latter was forced forward toward the periphery of the prothallium. As it is pushed forward by the elongation of the central cell, the neck-cell divides, so that before it reaches the periphery of the prothallium the archegonium has two distinct neck-cells. It may be mentioned that Shaw (I895) reported the 
presence of but a single neck-cell in Sequoia sempervirens, but this error has recently been corrected by Arnoldi (I900-I), who has found two. It was noticeable in examining my preparation that the two neck-cells were not always seen in longitudinal sections, but in cross-sections they were very distinctly made out. The neck-cells are not only to be distinguished by their position and shape, but their contents differ from those of other prothallial cells. The cytoplasm is devoid of large vacuoles, and, being highly dense and granular, stains more readily with the orange $G$. than do the other cells.

My observations agree with those of Arnoldi (I90I), both in regard to distribution of the archegonia over the upper half of the prothallium and that two is the typical number of neck-cells. I have, however, found four distinct neck-cells in a considerable number of archegonia (Fig. 24). This larger number is, however, exceptional. A somewhat similar variation in the number of neck-cells has been reported by Murrill (1900) for Tsuga, and according to Coker (I9OI) the number of cells in the neck of the archegonium in Podocarpus may vary from two to twenty-five.

It was interesting to observe the position that many of the archegonia take in relation to the pollen-tubes. Long before the archegonia are formed, the pollen-tubes have grown down and their courses are well established, so that their growth is not directed toward the archegonia. On the other hand, the growth of the archegonia is invariably directed towards one or the other of the pollen-tubes. It has been pointed out (p. 6$)$ that the course of the pollen-tube varies considerably. Some may grow down alongside the prothallium, others are partially surrounded by prothallial tissue, and others completely surrounded. In every case there were found numbers of archegonia pointing towards one or the other of the tubes, and their necks in contact with the tube-wall (Fig. 27).

For some time after the neck-cells have been organized, the central cell is completely filled with a very dense granular cytoplasm, in the centre of which is suspended a very large nucleus. The next step in the development of the egg-cell is important and interesting, because it bears directly on the question of the general occurrence of the ventral canal-cell in the Conifers. Arnoldi (I900), in his careful investigations, failed to find any vestige of such a cell in Sequoia. He also denies its existence in Cryptomeria, Cunninghamia, and Taxodium. On the other hand, the ventral canal-cell or nucleus has been found by Strasburger (1879) and Belajeff (1893) in Funiperus; by Blackman (1898), Chamberlain (1899), and Ferguson (I9OI) in Pinus; by Coker (I900-2) in Taxodium and Podocarpus; by Murrill (I900) in Tsuga; and by Land (I902) in Thuja. In Funiperus, Pinus, and Tsuga the spindle dividing the central nucleus into the egg and ventral nuclei has been described and figured, so that there can be little. doubt of its presence in these forms at least. 
After a very careful search I was unable to find the spindle that gives rise to the ventral canal-cell nucleus in Sequoia, but enough evidence was found to convince me that such a nucleus is cut off from the central nucleus. At a stage soon after the neck-cells have been organized, several archegonia showed two distinct nuclei in the cytoplasm. As shown in Fig. 22, the nuclei are of the same shape and size, and are situated at opposite ends of the archegonium. The nucleus at the base of the archegonium becomes the egg-nucleus, and there is little doubt that the one nearer the neck-cells represents a vestige of the ventral canal-cell. In Pinus and Tsuga distinct cell-plate is formed, which separates the ventral canal-cell from the egg-cell. In the majority of the Conifers investigated, however, the ventral canal-cell is only represented by a nucleus, no cell-plate being formed. This is evidently the case in Sequoia, for the ventral canal-cell nucleus functions no farther, and very soon becomes disorganized. In one or two archegonia it was found more or less flattened against the neck-cells, and in others it was more or less fragmented. That this is not the nucleus of the male cell was shown quite conclusively by the fact that the neck-cells were in no way disturbed. It apparently breaks down soon after it is cut off from the central nucleus. By the time the archegonium is ready for fertilization the ventral canal-cell nucleus has entirely disappeared. This very short period of its existence probably accounts for its having been overlooked by Shaw and Arnoldi.

Soon after the disappearance of the ventral canal-cell nucleus, the eggnucleus moves forward and occupies a position about halfway between the centre of the archegonium and the neck-cells. Meanwhile a large vacuole is developed in the lower part of the archegonium, as shown in Fig. 23. This figure shows a typical mature archegonium ready for fertilization.

\section{Fertilization.}

It has already been pointed out that the courses taken by the pollentubes have been well established long before the archegonia have been organized. It is therefore obvious that the direction taken by the tubes is not at all influenced by the female organ. On the other hand, however, it would seem that the pollen-tube had an influence upon the direction taken by the developing archegonia, for the growth of these latter structures is almost invariably directed towards the nearest tube. Fig. 27 shows how the archegonia appear in a cross-section of the prothallium. In this section there are four archegonia arranged in a semicircle, and with their neck-cells in contact with the wall of the pollen-tube. A longitudinal section would show ten to fifteen archegonia in a row, with the neck-cells directed toward the tube. The archegonia do not all point toward one tube, but each tube -and there are usually three or four present-has a number of archegonia directed toward it. Considering the diverse positions occupied by the 
tubes, this position is peculiar, as it suggests a case of the female organ seeking the male.

Owing to the large number of archegonia present, and their peculiar arrangement around the pollen-tubes, fertilization is easily accomplished. When the archegonia are mature, that portion of the wall of the tube opposite the opening between the two neck-cells is the only structure intervening between the egg and the male cells. At this time the two male cells have become spherical and lie one behind the other in the tube, and take up a position near the wall which touches the neck of the archegonia. The nucleus of the male cell is very large, containing one or two large nucleoli, and a very regular network of chromatin. The latter is in the form of small spherical granules suspended on the threads of linin. The egg-nucleus is slightly different in this respect. The chromatin here is much more finely granular, and consequently does not stain as deeply as the male nucleus.

The wall of the tube opposite the archegonium about to be fertilized apparently dissolves, for a small portion of the male cell now penetrates the archegonium by forcing the two neck-cells asunder, as shown in Fig. 29. Through the narrow communication thus established the male nucleus finds its way into the archegonium. As it squeezes through the narrow passage between the neck-cells, it becomes constricted and much elongated, as shown in Fig. $3 \mathrm{I}$, and immediately fuses with the egg-nucleus. It is a remarkable fact, as shown in Fig. 29, that only a very small amount of the cytoplasm of the male cell enters the archegonium. After the discharge of the nucleus into the archegonium, the greater part of the male cell remains outside and is discarded. As far as I am aware, such a condition has never before been reported for any of the Conifers, and it goes to establish the generally accepted view that the essential thing in fertilization is the fusion of the nuclei. As shown in Fig. 29, the denucleated male cell retains its spherical form, but has a vacuolated appearance in the central region once occupied by the nucleus. The section immediately following the one from which this figure was drawn showed the nucleus of this male cell in the act of fusing with the egg-cell in the archegonium. An examination of a large number of preparations has convinced me that this is the typical method of fertilization in Sequoia sempervirens. For some time after fertilization has been affected, the denucleated male cell is invariably found in the tube outside of the archegonia. Even as late as the early stages of development of the embryo, shrunken fragments of it were found. According to Coulter and Chamberlain (I90I), nearly the whole of the contents of the tube in Pinus is injected into the cytoplasm of the egg. Goroschankin (I 883 ) reports that both male cells pass into the archegonium, and Strasburger (I884) finds a similar occurrence in Picea vulgaris. In Pinus silvestris, Dixon (I 894) and Blackman ( 1898$)$ find that all the structures present in the pollen-tube pass into the egg. This has also been observed by Ferguson (I9OI) in 
Pinus Sirobus, in Taxodium by Coker (19c0), and in Cephalotaxus by Arnoldi (1900). It therefore happens that at the time of fusion of the male and female nuclei in many Conifers the archegonium contains both male cells as well as the stalk- and tube-nuclei. In his recent work on Thija, Land (1902) finds that the tube- and stalk-nuclei may sometimes enter the egg, but in the majority of cases they do not enter at all, but become disorganized in the space above the archegonium complex. Compared with these other Conifers, Sequoia sempervirens stands unique, in that only the nucleus and a very small amount of cytoplasm of the male cell enters the egg. Only the two sex-nuclei are present in the egg at the time of fusion.

As the male cell passes through the narrow canal of the neck, it immediately advances toward the egg-nucleus. As shown in Fig. $3^{\mathrm{I}}$, it has a long-drawn-out appearance. As it advances, the forward portion becomes rounded and very much wider than the long tapering hinder portion. While in this condition it first flattens against and then pushes in the membrane of the egg-nucleus. The long tapering end now draws in, and the male nucleus is more or less spherical. At the time of their fusion the male and female nuclei are of equal size, and in this respect differ from those in Tsuga and Pinus (Murrill, 1900; Blackman, 1898), where the male is much smaller than the female. Each cell has a large nucleolus, and the chromatin is in the form of small granules suspended in a regular network of linin threads. The chromatin in the female nucleus appears to be more finely granular than in the male, and consequently the male stained more deeply with safranin.

In Pinus the conjugation of the sexual nuclei has been worked out with considerable detail by Blackman (I 898), Chamberlain (1899), and Ferguson (I90I). According to these writers, the membranes of the sexual nuclei remain intact for some time after the penetration of the male into the fenale. Blackman further finds that the first segmentationspindle begins its formation before the male and female nuclei lose their identity. This has been partially confirmed by Chamberlain (I 899), and Ferguson (I90I), in Pinus, and by Woycicki (1899) in Larix, who were able to distinguish the male and the female chromatin as distinct groups inside the walls of the female nucleus.

In Sequoia sempervirens the behaviour of the conjugating nuclei differ slightly from that described above for Pinus and Larix. As the male nucleus pushes into the female it becomes only partially surrounded by the membrane of the latter. This is no doubt due to the fact that the conjugating nuclei in Sequoia are of equal size. The membrane separating the two nuclei apparently breaks down much earlier than in Pinus. The chromatic contents of the two nuclei flow together, forming a common network in which the male and female elements can no longer be distinguished.

The fusion-nucleus thus formed is very large and occupies a central 
position, and in the few cases observed the chromatin was in the spireme condition. From the fact that the first cleavage-spindle was frequently met with, and the fusion-nucleus in but a few cases, I conclude that a very short time intervenes between the conjugation of the sexual nuclei and the formation of the first cleavage-spindle.

Before passing on to the events that follow fertilization, we have yet to explain what becomes of the second male cell in Sequoia. Being functional, but unlike the other Conifers mentioned above, it does not fertilize the same archegonium. In Pinus (Blackman, I898) only one male nucleus is functional. This is also true for Cephalotaxus (Arnoldi, 1900), and probably for other Conifers. In these forms both male cells enter the same female organ, so that one pollen-tube can accomplish the fertilization of but one archegonium. In Sequoia sempervirens this is clearly not the case, for the two male cells of a single pollen-tube were found in the process of fertilizing two separate archegonia. The behaviour of the second male cell is a duplicate of that described for the first male cell. They discharge their nuclei into two neighbouring archegonia just about the same time. As each male cell functions in separate archegonia, we have in Sequoia a case where each pollen-tube may bring about the fertilization of two archegonia. As there are usually three or four pollentubes surrounded by a larger number of archegonia, and since each male cell fertilizes a separate archegonium, there may be as many as six or eight embryos developed. We shall see below that this generally happens.

\section{THE EMBRYo.}

As stated above, very little time elapses between the fusion of the male and female nuclei and the development of the first cleavage-spindle. This spindle was frequently met with, and always found with its poles in the long axis of the archegonium. In some cases observed the chromosomes were at the equator, or on the way to the poles; others again showed the daughter-nuclei already organized with the continuous fibrils connecting them. One of the most noticeable features of the spindle is the large number of chromosomes as compared with the number present in the gametophyte. As in the gametophyte, the chromosomes are very long $\mathrm{V}$-shaped structures, and after they have split and moved toward the poles they appear to be about half the size of the mother-chromosomes when at the equator. As near as could be estimated, there are about thirty-two chromosomes in the sporophyte and sixteen in the gametophyte. Fig. 32 shows the first cleavage-spindle of the sporophyte with the large $\mathrm{V}$-shaped chromosomes at the equator.

The events following the first cleavage-spindle proved to be very interesting, because they differ so widely from those of other Conifers in which the early stages of the embryo have been investigated. In most 
Conifers the fusion-nucleus gives rise to a number of free nuclei, which take up a position in the plane at the base of the oospore. These free nuclei, by dividing, give rise to three tiers of cells with complete walls. The uppermost of the three tiers remains in the oospore, the middle tier develops the suspensors, and the lowest tier the embryo. This is no doubt true for Pinus and many other Conifers, but in Sequoia the embryo develops in quite another way.

Soon after the daughter-nuclei of the first cleavage have been organized, a cell-plate is formed between them, and this results in the development of two distinct cells, each surrounded by its own cell-wall. The first cleavage, therefore, does not result in the formation of free nuclei. Fig. 33 shows the two daughter-nuclei of the first cleavage. It also shows the cell-plate developing on the kinoplasmic fibrils which extend between the nuclei. The two cells thus organized from the first division occupy almost the entire cavity of the oospore, and lie one behind the other. These two cells now divide in the same plane as the first division, and the pro-embryo now consists of a single row of four large cells, as shown in Fig. 34. An examination of this figure makes it apparent that the division of the first two cells of the pro-embryo is nearly or quite simultaneous. In this connexion it is interesting to note that Arnoldi reports the presence of but three cells in the embryo at this time. He states that the uppermost cell of the first cleavage functions no further, but that the lower one divides and organizes two cells which become the suspensor and the embryo proper respectively. As shown in Fig. 34, there can be no doubt as to the division of both daughter-nuclei of the first cleavage.

The next stage observed showed five cells in the oospore, and, judging from the position of them, the fifth one arises by a division of the lowest cell in the row of four. The five cells take up a position as shown in Fig. 35. The fifth or lowest cell in the row now enlarges and divides. Of the last two cells thus organized, the end one becomes the embryo proper and the other one develops into the suspensor. As soon as the embryo-cell and the suspensor-cell are organized the latter enlarges very rapidly and becomes very much elongated. As it increases in length it bends downward and carries the embryo-cell, at its apex, down through the endosperm. As the embryo forces its way through the prothallial tissue the cells of the latter show every sign of disorganization, and are no doubt absorbed by the developing embryo. Fig. 37 shows a suspensor with its large single nucleus and a two-celled embryo at its apex.

\section{SUMmaRY.}

For some time after the separation of the tetrads, the microspore contains a single nucleus. Before leaving the sporangium this nucleus divides, so that at the time of pollination there are two nuclei present. 
The larger of these nuclei is the tube-nucleus, and the smaller, which is situated near the wall of the spore, is the generative nucleus. No trace of nuclei or cells representing the vegetative tissue of the male gametophyte were found.

No further division of the nuclei in the pollen-grain takes place until the pollen-tubes are partially developed. There are usually three or four pollen-tubes present, and they pursue different courses. One or two of them may grow down between the nucellus and the integument for a considerable distance, while others penetrate the nucellus immediately at the apex.

Just about the time the tube penetrates the nucellus the generative nucleus divides, giving rise to the stalk- and body-nuclei.

The body-nucleus becomes very large, and surrounds itself with a zone of dense cytoplasm, which in turn is surrounded by a membrane. The tube now contains one large cell and two free nuclei.

During the latter part of June the body-cell divides and gives rise to two male cells. At first the male cells are flat on one side but soon become spherical. They are of equal size and both are functional.

There are from four to six macrospore mother-cells organized from centrally situated hypodermal cells of the macrosporangium. Each mother-cell divides twice, but one cell fails to develop into a spore, so that there are from eight to twelve macrospores formed. The first is the reduction-division which marks the beginning of the gametophyte. It takes place about the first of March.

Each macrospore begins to germinate. Some of the spores enlarge more rapidly than others, but the enlargement is always accompanied by a nuclear division. Although of various shapes and sizes, each macrospore now contains two free nuclei. The majority of the sacs or young prothallia show no further development, but two or three of them grow very rapidly and extend down through the tissue of the nucellus in the direction of the chalaza.

Of the two or three sacs that continue their growth, one develops much more rapidly than the other one or two. In the early stages of the prothallium there is a progressive and simultaneous division of the free nuclei. These are at first distributed throughout the length of a long central strand of cytoplasm. By the development of large vacuoles which eventually fuse together, the cytoplasm and the free nuclei are forced to the wall. The prothallium at this time consists of a very large central vacuole, surrounded by a parietal layer of cytoplasm in which the numerous free nuclei are distributed.

As the prothallium increases, the nuclei divide rapidly and frequently. The cytoplasm and nuclei now accumulate in great abundance in the lower, and less so in the upper portions, and the vacuole is reduced 
to a comparatively small narrow area in the upper half of the prothallium.

The final division of all the free nuclei which immediately precedes the formation of the cellular endosperm is almost simultaneous. The spindlefibrils which connect the daughter-nuclei in this division persist and increase in numbers, so that each nucleus is surrounded by a system of delicate radiating kinoplasmic fibrils. These fibrils not only connect with the sister-nuclei but reach out and join the fibrils of the neighbouring nuclei. The result is that large numbers of nuclei become joined together by radiating systems of kinoplasmic fibrils. The cell-plates are formed in the usual way between the nuclei. The formation of the endosperm in Sequoia sempervirens therefore does not follow the method described by Sokolowa (189I) for other Coniferales.

As the vacuole in the upper region disappears, the cells in this region are very large and elongated, and these structures are no doubt the 'Alveolen' described by Arnoldi. The archegonia are, however, not confined to this tissue in the prothallium.

During the development of the primary prothallium one or two secondary prothallia advance much more slowly. Their growth is confined to the narrow limits left by the primary prothallium. Their form is therefore very irregular, and they never develop cellular tissue. The cells of the primary prothallium which are in contact with the protoplasm of the secondary prothallia act as absorbing organs. This absorption of the protoplasmic substance of the secondary prothallium by the cells of the primary prothallium no doubt retards the development of the former and prevents it from forming tissue.

Soon after the endosperm is formed, certain cells deep within the upper portion of the prothallium become differentiated into archegonial initials. When quite small the primary neck-cell is cut off, and the central cell enlarges rapidly and carries the primary neck-cell forward towards a pollen-tube. During the enlargement of the central cell the primary neckcell divides once. Occasionally four neck-cells were formed in the archegonium, but two seemed to be the typical number. Just before the archegonium has reached its full size the central nucleus evidently divides, for we now have two large nuclei present. These nuclei are of equal size, and are situated at opposite ends of the archegonium. The one near the neck represents the ventral canal-cell, and the lower one is the egg-nucleus. The ventral canal-nucleus very soon becomes disorganized and disappears entirely. The lower portion of the archegonium develops a large vacuole, and at the time of fertilization the egg-nucleus is centrally situated. As the archegonia develop, their elongation is always directed towards a pollen-tube, so that each tube becomes partially surrounded by the necks of several archegonia. 
As soon as the archegonia are mature and ready for fertilization, the two male cells move toward the wall of the pollen-tube and take up positions immediately opposite the necks of two neighbouring archegonia. The wall of the male cell and of the tube in the region opposite the neckcells evidently become dissolved, for the nucleus of the male cell, with a very small amount of cytoplasm surrounding it, squeezes through the narrow canal between the neck-cells and immediately advances toward the egg-nucleus. During its passage through the canal the male nucleus becomes very much constricted and elongated, but as it approaches the egg-nucleus it soon resumes its spherical form. The denucleated male cell remains outside of the archegonium and retains its spherical form for some time after fertilization has been effected, when it becomes disorganized. The nuclei of both male cells are functional, but they fertilize two neighbouring archegonia.

At the time of fusion the sex-nuclei are of equal size, and as the male pushes against the female it becomes partially surrounded by the membrane of the latter. The chromatin of both nuclei are in the spireme stage, and when the membrane between the two breaks down, a common chromatin network is formed in which the male and female elements can no longer be distinguished.

Very soon after the complete fusion of the sex-nuclei the first cleavagespindle is developed. There are no free nuclei formed in the pro-embryo. The first cleavage results in the formation of two distinct cells, each surrounded by a complete cell-wall. Both of these cells divide, so that the embryo now consists of a row of four cells. The lowest of these enlarges and divides again. The two cells resulting from this last division give rise to the suspensor and embryo proper. Each fertilized archegonium gives rise to but a single embryo.

As near as could be estimated, there are sixteen chromosomes in the gametophyte and thirty-two in the sporophyte.

In conclusion, I wish to express my sincere thanks to my friend Capt. C. B. Hudson, who assisted me in collecting material.

\section{NoTE.}

Since the above went to press Dr. Coker's valuable work (1903) on Taxodium has appeared. I regret that it is too late to make a detailed comparison of Sequoia and Taxodium as worked out by Dr. Coker, as the two forms differ so widely in every essential detail. They should certainly be placed in different families. 


\section{LITERATURE CITED.}

ARNOLDI, W. ('00): Beiträge zur Morphologie und Entwicklungsgeschichte einiger Gymnospermen.

I. Die Entwicklung des Endosperms bei Sequoia sempervirens. Bull. Soc. Imp. Nat. Moscou, I900.

Beiträge zur Morphologie und Entwicklungsgeschichte einiger Gymnospermen.

II. Ueber die Corpuscula und Pollenschläuche bei Sequoia sempervirens. Bull. Soc. Imp.

Nat. Moscou, I900.

('01) : Beiträge zur Morphologie und Entwicklungsgeschichte einiger Gymnospermen.

V. Weitere Untersuchungen über die Embryologie in der Familie der Sequoiaceen. Bull.

Soc. Imp. Nat. Moscon, I 901 .

Belajeff, W. ('93): Zur Lehre von dem Pollenschlauche der Gymnospermen. Ber. der Deutsch. Bot. Gesell. II, p. 196.

Blackman, V. H. ('98): On the Cytological Features of Fertilization and Related Phenomena in Pinus silvestris (L.). Phil. Trans. Roy. Soc. I90, p. 395.

CAMpbell, D. H. ('02): A University Textbook of Botany. New York, igo2.

Chamberlain, C. J. ('99): Oogenesis in Pinus Laricio. Bot. Gaz. xxvii, p. 268.

Coker, W. C. ('00): Observations on the Gametophyte and Embryo of Taxodium distichum. Johns Hopkins Univ.

p. 89.

('02): Notes on the Gametophytes and Embryo of Podocarpus. Bot. Gaz. xxxiii, ('03): On the Gametophytes and Embryo of Taxodium. Bot. Gaz. xxxvi, pp. I and 114,1903 .

Coulter, J. M., and Chamberlain, J. C. ('01): Morphology of Spermatophytes. Part I. New York, I90I.

Dixon, H. N. ('94): Fertilization in Pinus silvestris. Ann. Bot. viii, p. 2 r.

Ferguson, M. C. ('01): The Development of the Pollen-tube and the Division of the Generative Nucleus in certain Species of Pinus. Ann. Bot. xv, p. 193.

Bot. xv, p. 435 .

Goroschankin, J. ('83): Zur Kenntniss der Corpuscula bei den Gymnospermen. Bot. Zeit. xli, p. 825 .

Hirasé, S. ('95): Études sur la fécondation et l'embryogénie du Ginkgo biloba. Jour. Coll. Sci. Imp. Univ. Tokyo, viii, p. $3 \circ \%$.

Ikeno, S. ('96): Das Spermatozoid von Cycas revoluta. Bot. Mag. Tokyo, x, p. 367 .

JÄGER, L. ('99) : Beiträge zur Kenntniss der Endospermbildung und zur Embryologie von Taxus baccata. Flora, lxxxvi, p. $24 \mathrm{I}$.

LAND, W. J. G. ('02): A morphological Study of Thuja. Bot. Gaz. xxxvi, p. 249.

Lotsy, J. P. ('99): Contribution to the Life-history of the Genus Gnetum. Ann. Jard. Bot. Buitenzorg, II. i, p. 46.

Murrill, W. A. ('00): The Development of the Archegonium and Fertilization in the Hemlock Spruce (Tsuga Canadensis). Ann. Bot. xiv, p. $5^{8} 3$.

PeIrce, G. J. ('01) : Studies on the Coast Redwood, Sequoia sempervirens. Cal. Acad. Sci., 3rd ser. Bot. ii. 3 .

SHaw, W. R. ('96) : Contribution to the Life-history of Sequoia sempervirens. Bot. Gaz. xxi, p. $33^{2}$.

Sokolowa, Mlle C. ('90): Naissance de l'endosperme dans le sac embryonnaire de quelques gymnospermes. Bull. Soc. Imp. Nat. Moscou, I 890 (I89I), p. 446.

Strasburger, E. ('72) : Die Coniferen und Gnetaceen, 1872.

('97): Die Angiospermen und die Gymnospermen, 1879.

('84): Neue Untersuchungen über die Befruchtungsvorgänge bei den Phanerogamen als Grundlage für eine Theorie der Zeugung. Jena, $\mathbf{1} 884$.

Timberlake, H. G. ('00) : The Development and Function of the Cell-plate in Plants. Bot. Gaz. $\mathrm{xxx}, \mathrm{p} .73$. 
Webber, H. J. ('97) : Peculiar Structure in the Pollen Tube of Zamia. Bot. Gaz. xxiii, p. 453. The Development of the Antherozoids of Zamia. Bot. Gaz. xxiv, p. I6.

Notes on the Fecundation of Zamia and the Pollen Tube Apparatus of Ginkgo. Bot. Gaz. xxiv, p. 225 .

('01) : Spermatogenesis and Fecundation of Zamia. U. S. Dept. Agri. Bur. of Plant Industry. Bull. ii, I90I.

Woycicki, Z. ('99): Fertilization in the Coniferae. Warschau, 1899. Reviewed in Jour. Roy. Micro. Soc. p. 482 , 1900.

\section{EXPLANATION OF FIGURES IN PLATES I-IV.}

\section{Illustrating Dr. Lawson's Paper on Sequoia sempervirens.}

All the figures refer to Sequoia sempervirens, and were drawn with the aid of the Camera lucida. For the finer cytological details, Zeiss's homogeneous immersion obj. $\frac{1}{12}$ apert. 1.25 with compensating ocular No. 6 , and for the lower magnifications obj. $\frac{1}{3}$ and $\frac{1}{6}$ and ocular No. 4 , were used,

Fig. I. A microspore as it appeared about two weeks before pollination, showing the single centrally situated nucleus. Material collected Dec. I5, I90 I. $\times 900$.

Fig. 2. A microspore at the time of pollination, showing the large centrally situated tube-nucleus $(t . n$.$) and the smaller laterally situated generative nucleus (g . n$.). Jan. I, I902. $\times 900$.

Fig. 3. A longitudinal section of the ovule, showing the relative height of the macrosporangium and the integument. The micropyle is nearly closed, and the pollen-tubes are shown growing down between the sporangium and the integument. Within the sporangium six macrospore mother-cells are represented. Material collected March I 2, 1902. $\times 125$.

Fig. 4. A pollen-tube penetrating the nucellus near the top. The generative nucleus has divided, so that there are now three free nuclei in the tube. The large tube-nucleus $(t . n$.$) is in$ advance of the stalk- $\left(S . n\right.$.), and the body- $\left(B . n\right.$.) nuclei, $\times 75^{\circ}$.

Fig. 5. The lower part of the pollen-tube, showing the body-cell (b. c.) fully organized and the stalk-nucleus lying close beside it. Material collected June I2, 1902. $\times 75^{\circ}$.

Fig. 6 . The tip of the pollen-tube containing the tube-nucleus $(t . n$.), the stalk-nucleus $(S, n$.), and the large body-cell $(b . c$.$) in the rear. Material collected June { }_{5}$, $1902 . \times 75^{\circ}$.

Fig. 7. The body-cell undergoing division. The daughter-nuclei are organized and are connected by a series of kinoplasmic fibrils. The fibrils curve out toward the cell-wall in preparation for cell-plate formation. Material collected June 29, 1902. $\times 750$.

Fig. 8. Two male cells as they appear immediately after the division of the body-cell. At this time they are flat on one side, and each contains a large centrally situated nucleus. Material collected June $29,1902 . \quad \times 75^{\circ}$.

Fig. 9. A longitudinal section through the central portion of the macrosporangium, showing six macrospore mother-cells. The cytoplasm of these cells is very dense and granular. The nuclei are comparatively large, and judging from the condition of the chromatin they are preparing for mitosis. Material collected March 2, I902. × 800.

Fig. 10. Section same as Fig. 9. The macrospore mother-cells are undergoing division. Two spindles of the reduction-division are shown. March I2, $1902 . \quad \times 800$.

Fig. II. A longitudinal section through the macrosporangium, showing eight germinating macrospores or young prothallia. Three of the prothallia are larger than the others, and each contains two nuclei. Their growth is directed towards the chalaza. April 25, I902. $\times$ I 75.

Fig. I2. A longitudinal section, showing two young prothallia after repeated nuclear division. The free nuclei are distributed along a central strand of cytoplasm which extends from end to end of the prothallium. April 25, $1902 . \times 175$.

Fig. 13. A longitudinal section of a primary prothallium at a later stage, showing the very large central vacuole and parietal layer of cytoplasm in which the free nuclei are distributed. June 8 , 1902. $\times 175$. 
Fig. I4. A longitudinal section of the middle and lower portion of the prothallium, showing the accumulation of cytoplasm and free nuclei, and the corresponding decrease in the size of the vacuole. The free nuclei have increased enormously in numbers, and are distributed uniformly throughout the cytoplasm. June 8, $1902 . \times 175$.

Fig. 15. From a longitudinal section of the prothallium immediately after the final division of the free nuclei. Each nucleus is surrounded by a system of kinoplasmic radiations in such a way that a large number of nuclei are connected together by fibrils. This is the first step in preparation for cell-plate formation. June $\mathrm{I} 2,1902 . \times 1000$.

Fig. 16. A section of endosperm, showing a stage immediately following that shown in Fig. I 5 . The cell-plate has developed from the kinoplasmic fibrils stretching between the nuclei. Between some of the nuclei the cell-plate is already fully formed, while in others the granules are seen on the fibrils which eventually become the cell-plate. June I2, I902. $\times 1000$.

Fig. I7. A longitudinal section of the upper portion of the prothallium, showing the distribution of the archegonia. The archegonia are shown in various stages of development. Archegonial initials, jacket-cells, and mature archegonia are shown in the same region. The growth of the older archegonia is directed toward the periphery of the prothallium. July 8, 1902. $\times$ about I 50.

Fig. I8. A longitudinal section, showing a secondary prothallium in an advanced stage of development. The primary prothallium has already developed cellular tissue, and the course of the secondary appears to wind in and out through this. June $29,1902 . \times$ I 50.

Fig. 19. A cross-section, showing the close relationship between the primary and secondary prothallia. The cells of the primary prothallium in contact with the secondary extend outward and act as absorbing organs. These cells extend into the protoplasm of the secondary prothallium in a dovetail fashion, and their nuclei are very large and have the appearance of being engaged in very active metabolism. June $27,1902 . \times 100$.

Fig. 20. An archegonial initial in process of division. The spindle shows the large V-shaped chromosomes on the way to the poles. The cells resulting from this division are the central cell and the primary neck-cell. In order to bring out more clearly the character of the chromosomes, the figure was drawn at a somewhat higher magnification than the other figure of the archegonium. June $25,1902 . \quad \times 850$.

Fig. 2I. A young archegonium, showing the large central cell and the small primary neck-cell. June $25,1902 . \times 750$.

Fig. 22. A later stage of the archegonium, showing two neck-cells. The archegonium contains two large nuclei of equal size. The nucleus nearer the neck is the ventral-canal nucleus, and the one at the opposite end is the egg-nucleus. June $25,1902 . \quad \times 750$.

Fig. 23. A typical mature archegonium ready for fertilization. There are two neck-cells present. The ventral-canal nucleus has disappeared, and the egg-nucleus is centrally situated. A large vacuole occupies the lower portion of the archegonium. June $29,1902 . \quad \times 75^{\circ}$.

Fig. 24. A mature archegonium, showing four distinct neck-cells. June $29,1902 . \quad \times 750$.

Fig. 25. A cross-section of a pollen-tube completely surrounded by female prothallial tissue. The tube contains the body-cell and the tube- and stalk-nuclei. June $25,1902 . \times$ I50.

Fig. 26. A cross-section of the upper portion of the female prothallium, showing the position of the archegonial initials and jacket-cells when they first become differentiated. June $25, \mathbf{1 9 0 2}$. $\times 100$.

Fig. 27. A cross-section of the upper portion of the female prothallium. The prothallial tissue partially surrounds a pollen-tube. Four mature archegonia are shown with their necks in contact with the wall of the tube. This position of the mature archegonia in relation to the pollen-tubes is very characteristic. June $27,1902 . \times 100$.

Fig. 28. A cross-section of the female prothallium, showing sections of their pollen-tubes. As shown in this figure, the outline of the prothallium is always modified to the shape and position of the pollen-tubes. Two of the tubes show the male cell. June $25,1902 . \times 100$.

Fig. 29. A denucleated male cell as it appears after the nucleus has been injected into the egg. It retains its spherical form, but the central region once occupied by the nucleus is distinctly vacuolated. The figure shows quite clearly that only a very small amount of cytoplasm from the male cell accompanies the nucleus through the narrow canal between the neck-cells into the egg. June 25,1902 . $\times 75$.

Fig. 30. An archegonium immediately after the entrance of the male nucleus. The male nucleus is shown pushing in the wall of the female. June $25,1902 . \times 750$. 
Fig. 31. Another stage in the fusion of the male and female nuclei. The rear portion of the male nucleus has a long-drawn-out appearance, due to its passage through the narrow canal between the neck-cells. June $27,1902 . \quad \times 750$.

Fig. 32. The first cleavage-spindle with the large V-shaped chromosomes at the equator. June $25,1902 . \quad \times 750$.

Fig. 33. A later stage of the first cleavage-spindle with the daughter-nuclei organized at the poles, and the cell-plate developing from the continuous fibrils. June $25,1902 . \times 750$.

Fig. 34. Each daughter-nucleus of the first cleavage has divided, so that the pro-embryo now consists of four cells placed one behind the other, and each surrounded by a distinct cell-wall. June $25,1902 . \times 750$.

Fig. 35. A later stage of the embryo, showing five distinct cells. June 25, 1902. $\times 75$.

Fig. 36. An early stage in the development of the suspensor with the first cell of the embryo proper at its apex. June $25,1902 . \times 75^{\circ}$.

Fig. 37. A later stage of the suspensor, showing its single large nucleus and two cells of the embryo proper as it is carried forward down through the endosperm. July $8,1902 . \quad \times 750$. 
G. N
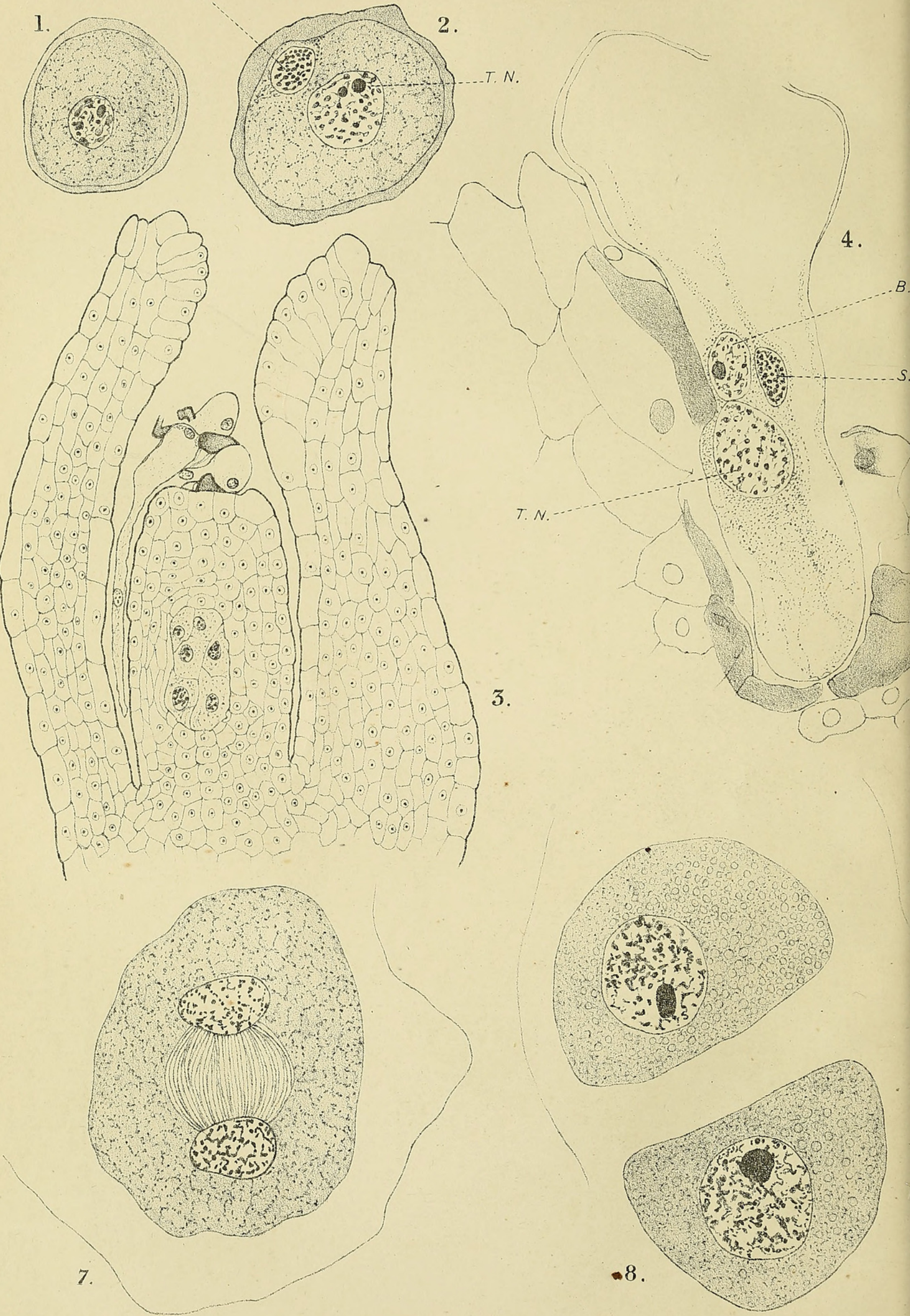
5.

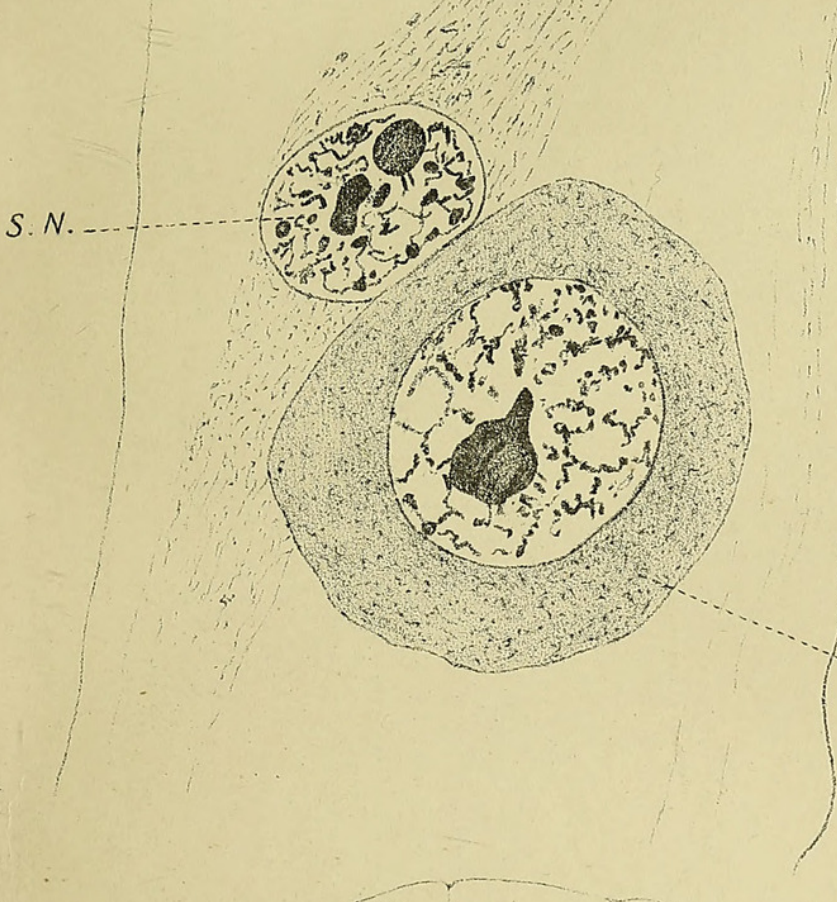

6.
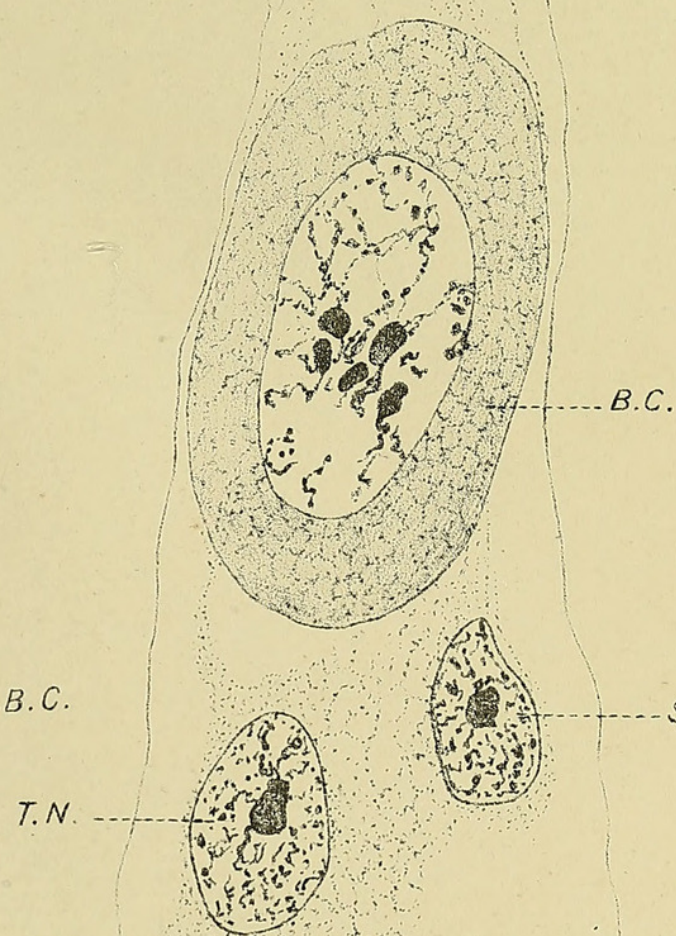

$-S . N$

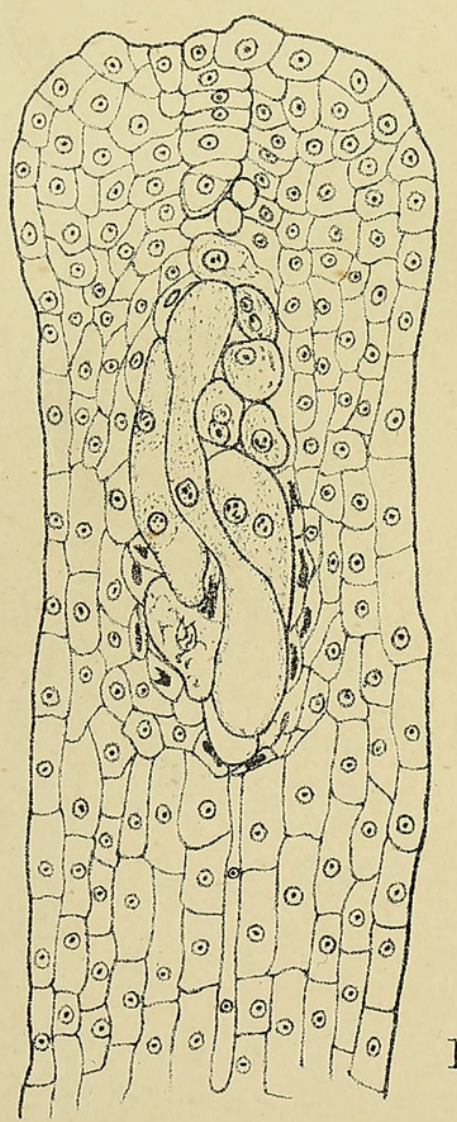

11. 

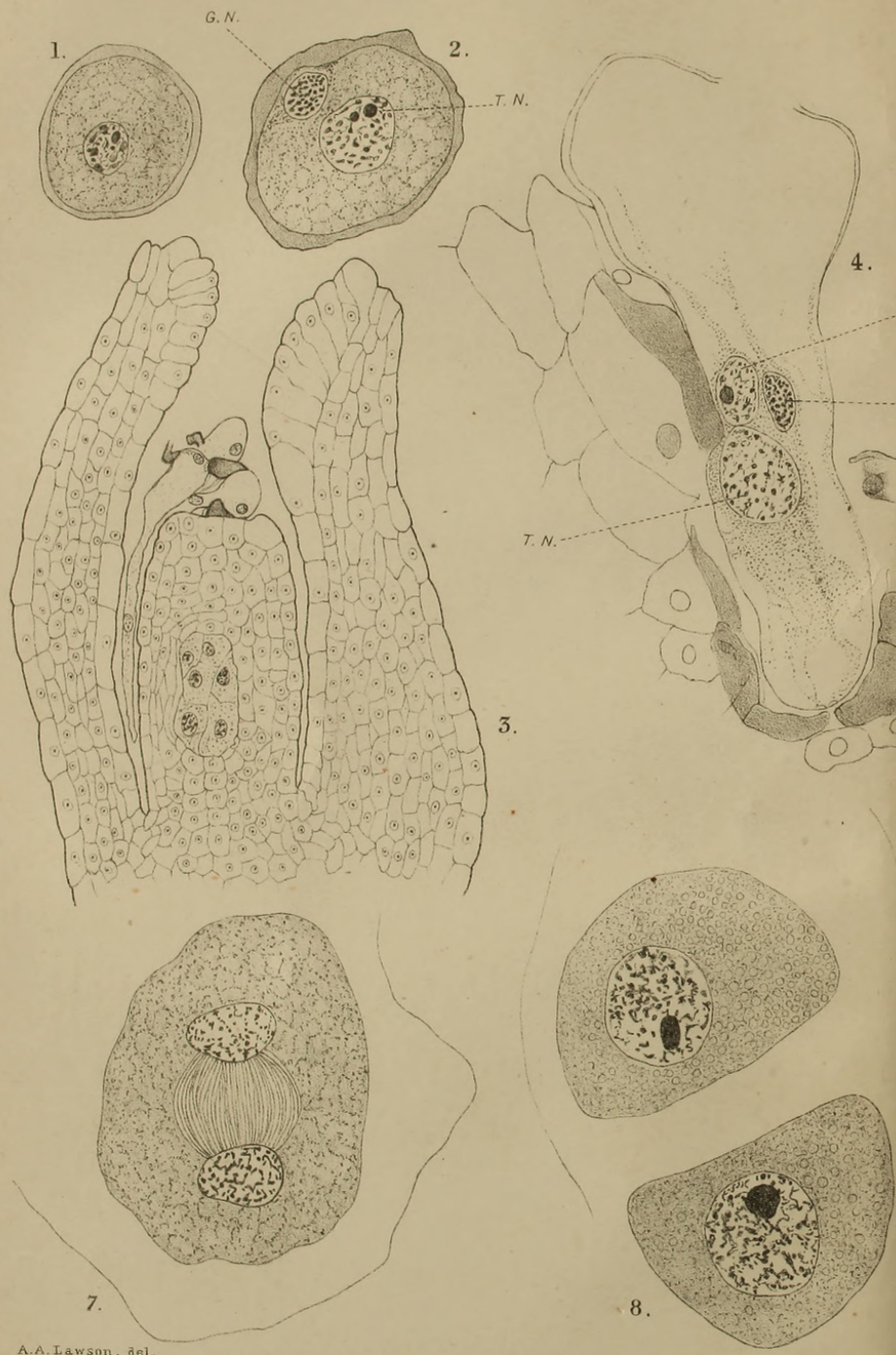

LAWSON, - GAMETOPHYTES OF SEQUOIA.
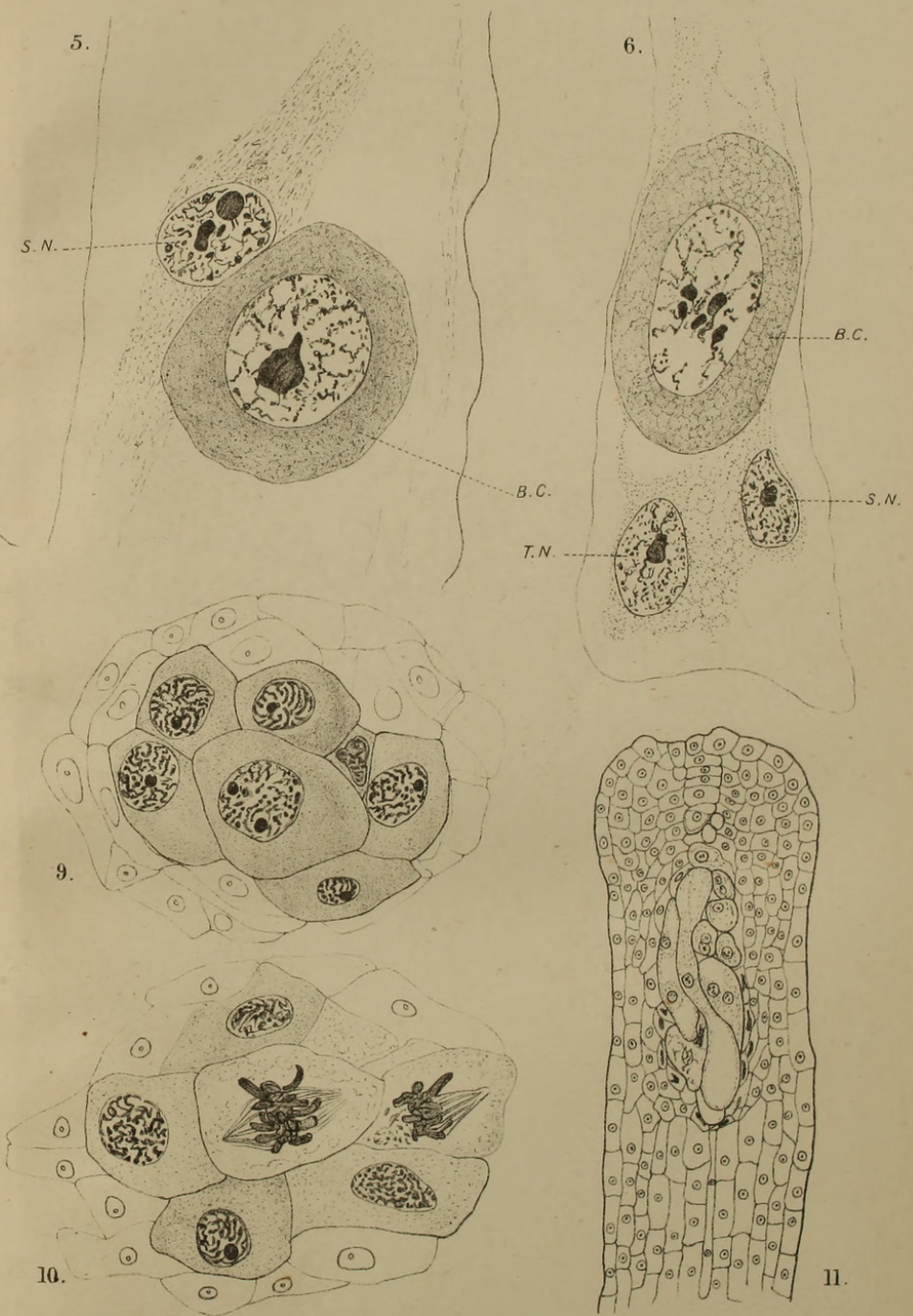


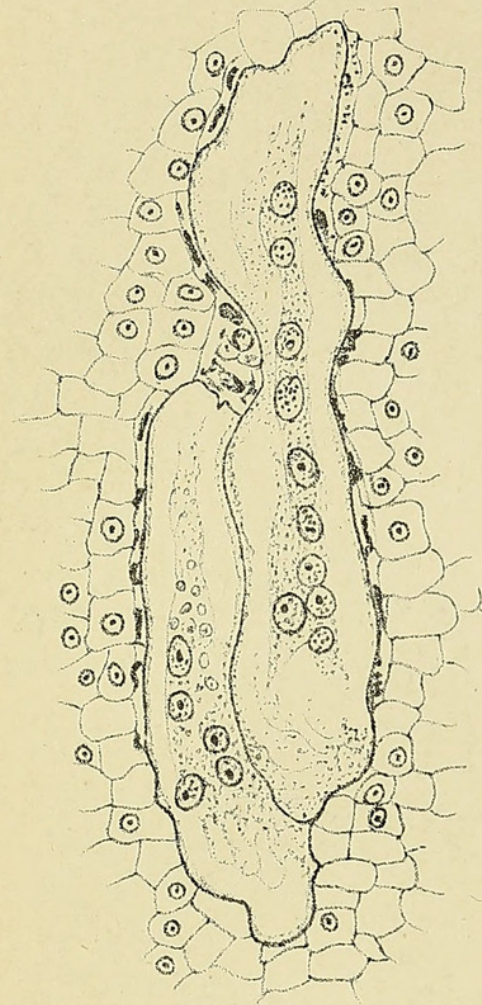

12.

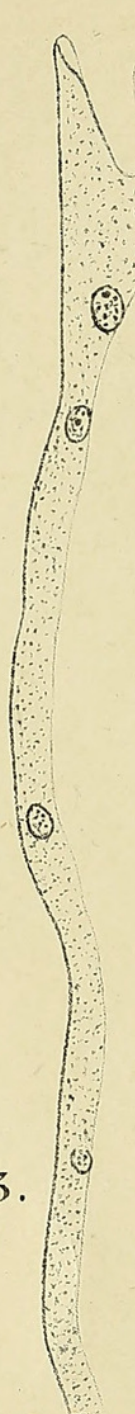

(9)

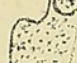

(2) (2) 9 (0) 0 (0)

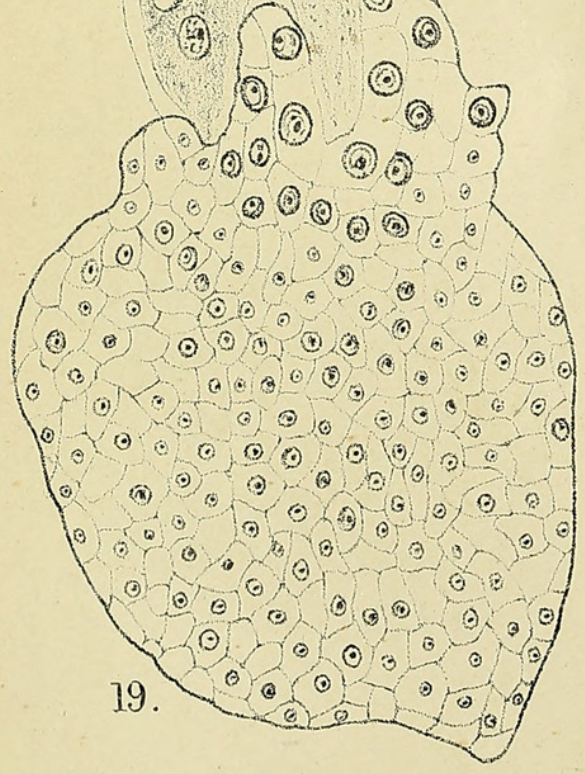

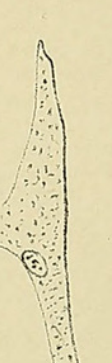

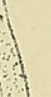

6.

2

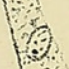

1.

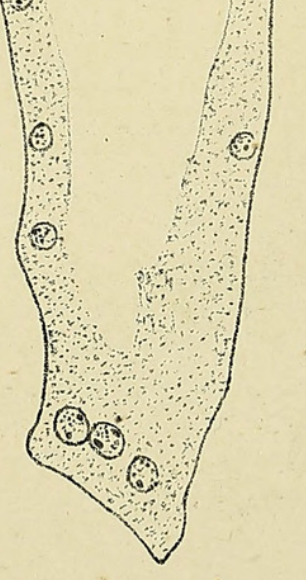

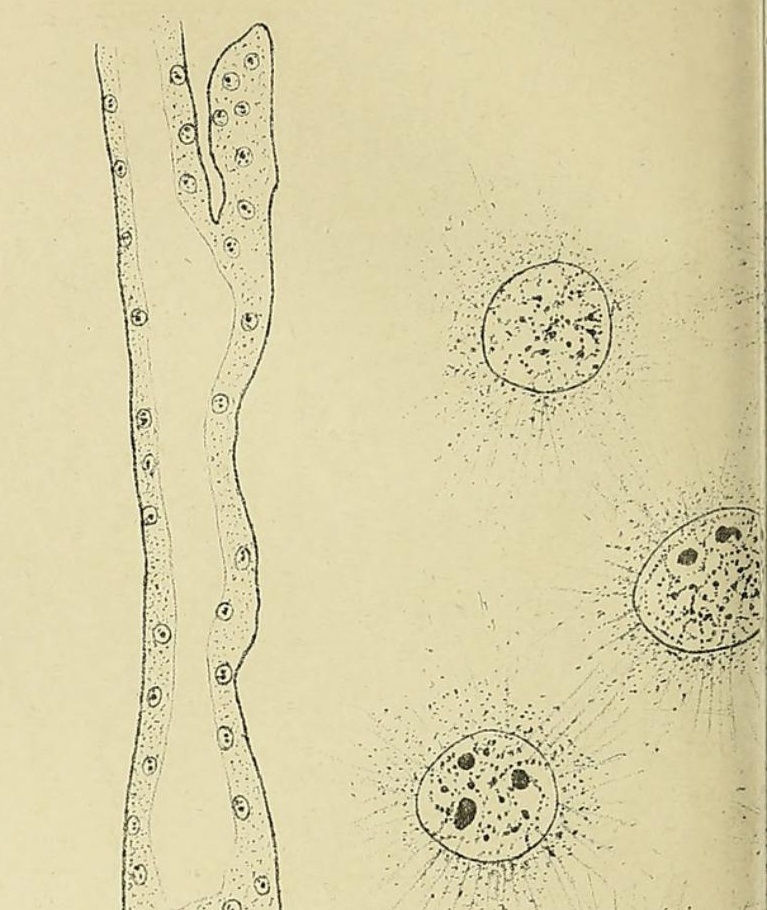

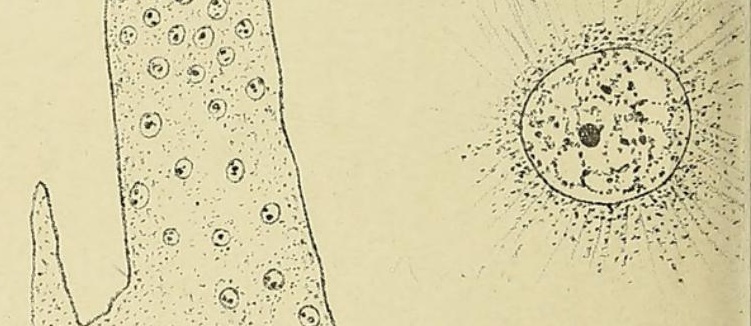

15.

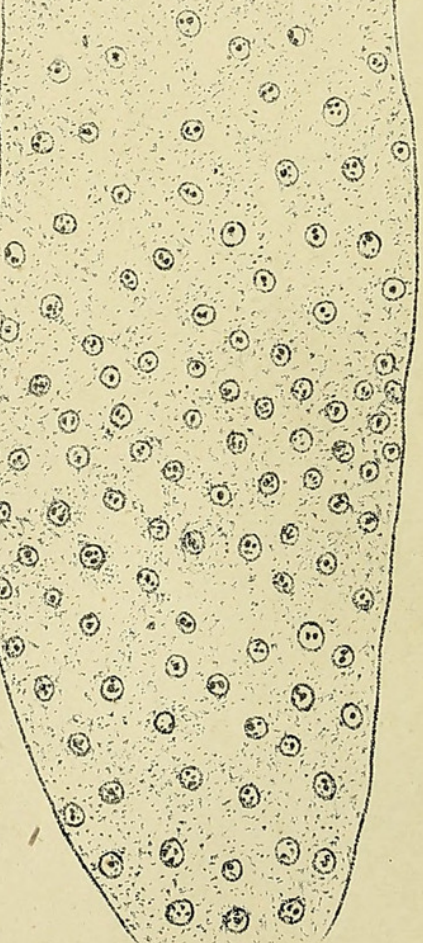

$\left.\begin{array}{ccc}0 & 0 & 0 \\ 0 & 0 & 0 \\ 0 & 0 & 0 \\ 0 & 0 & 0\end{array}\right]$

. 



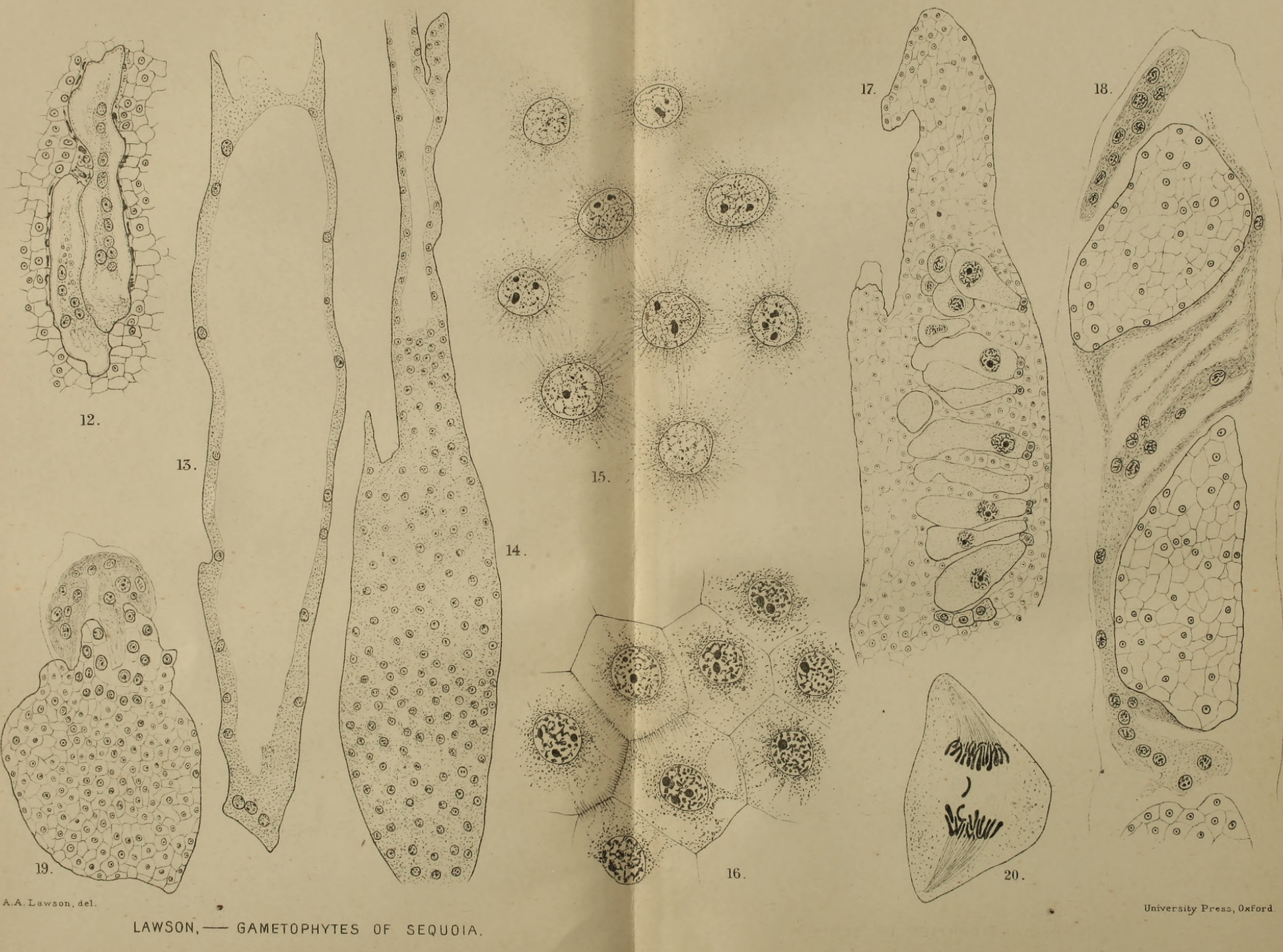



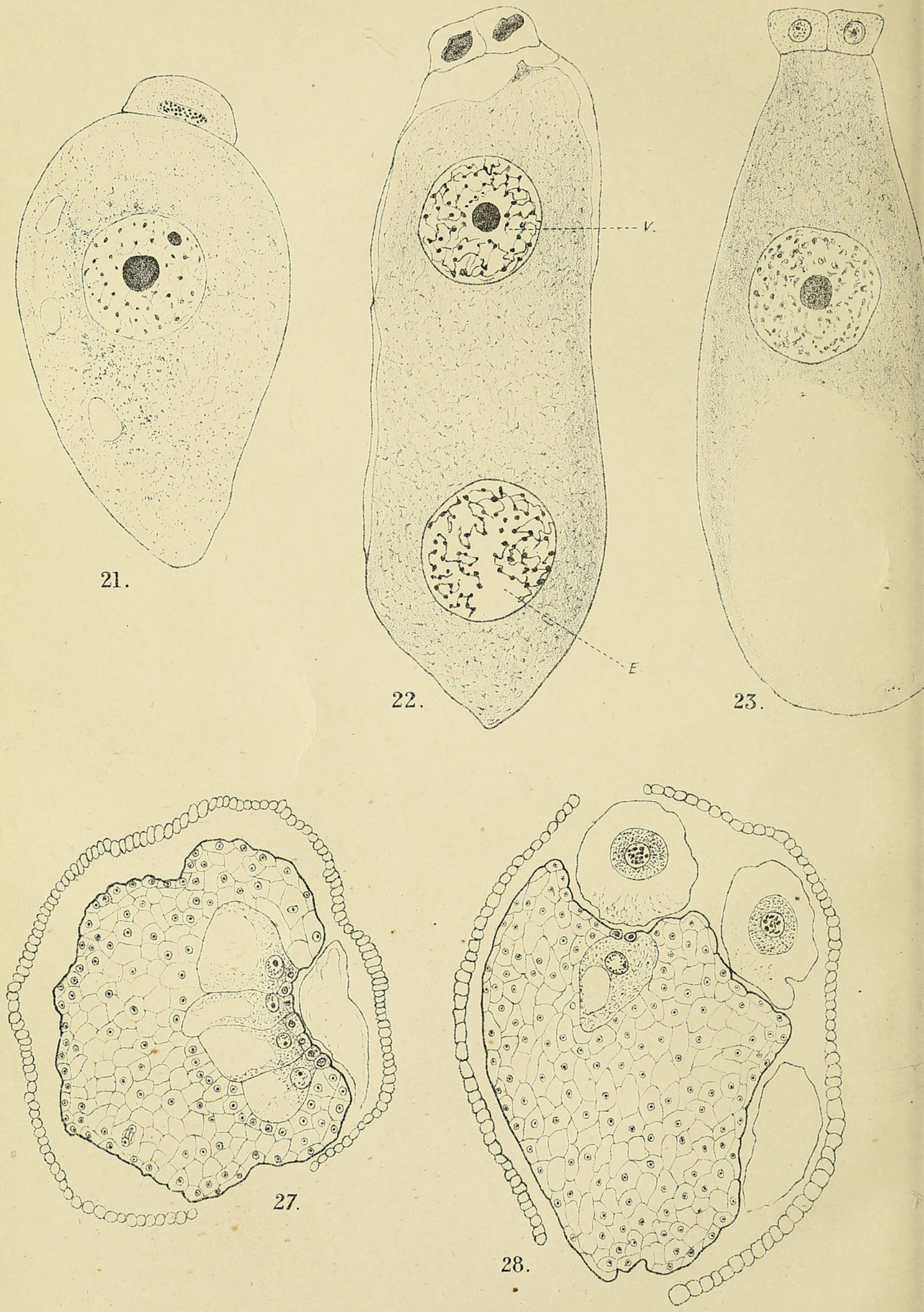

A. A. I. awson, del 
Vol. XVIII, Pl. III.
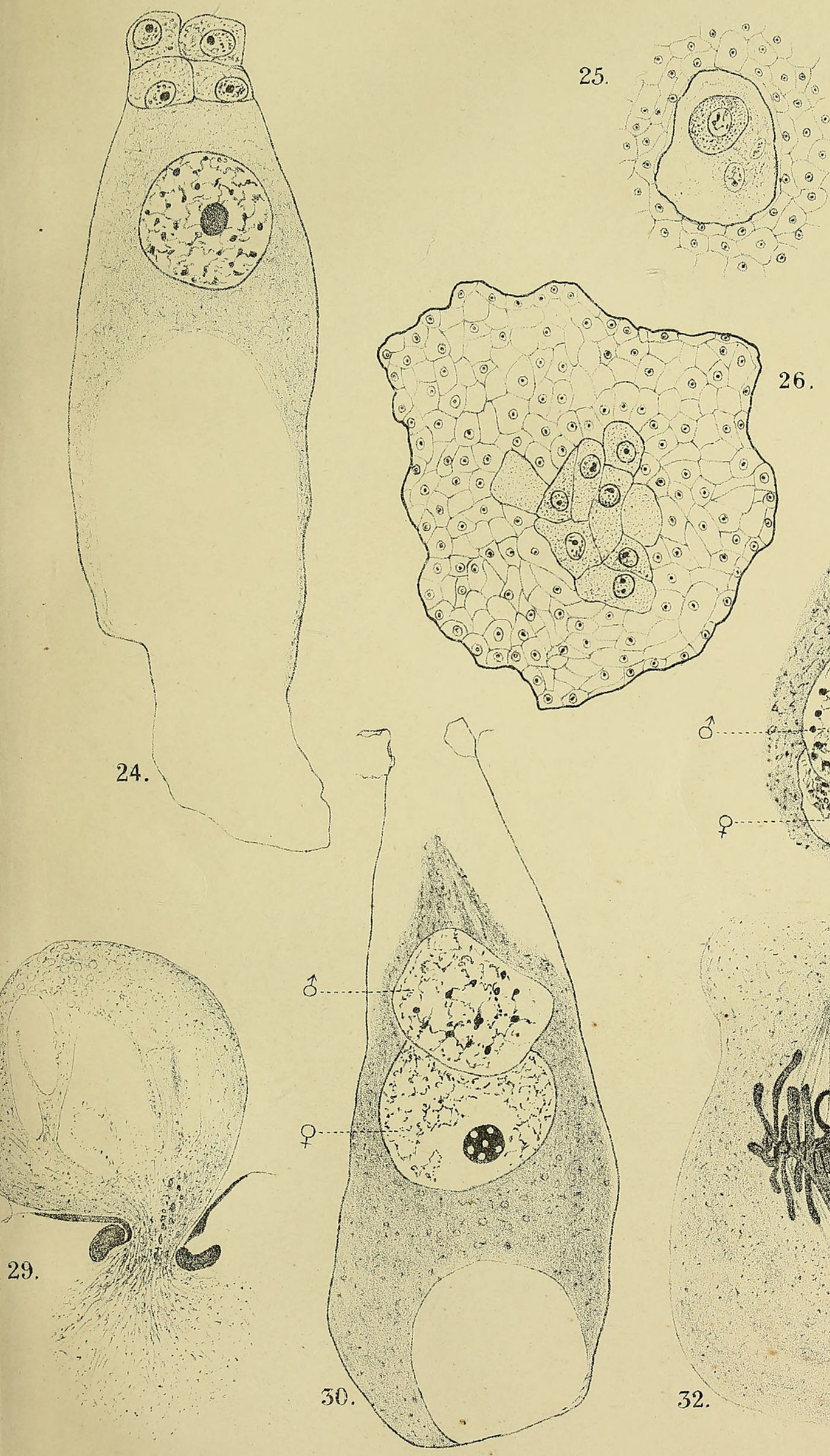

29. 

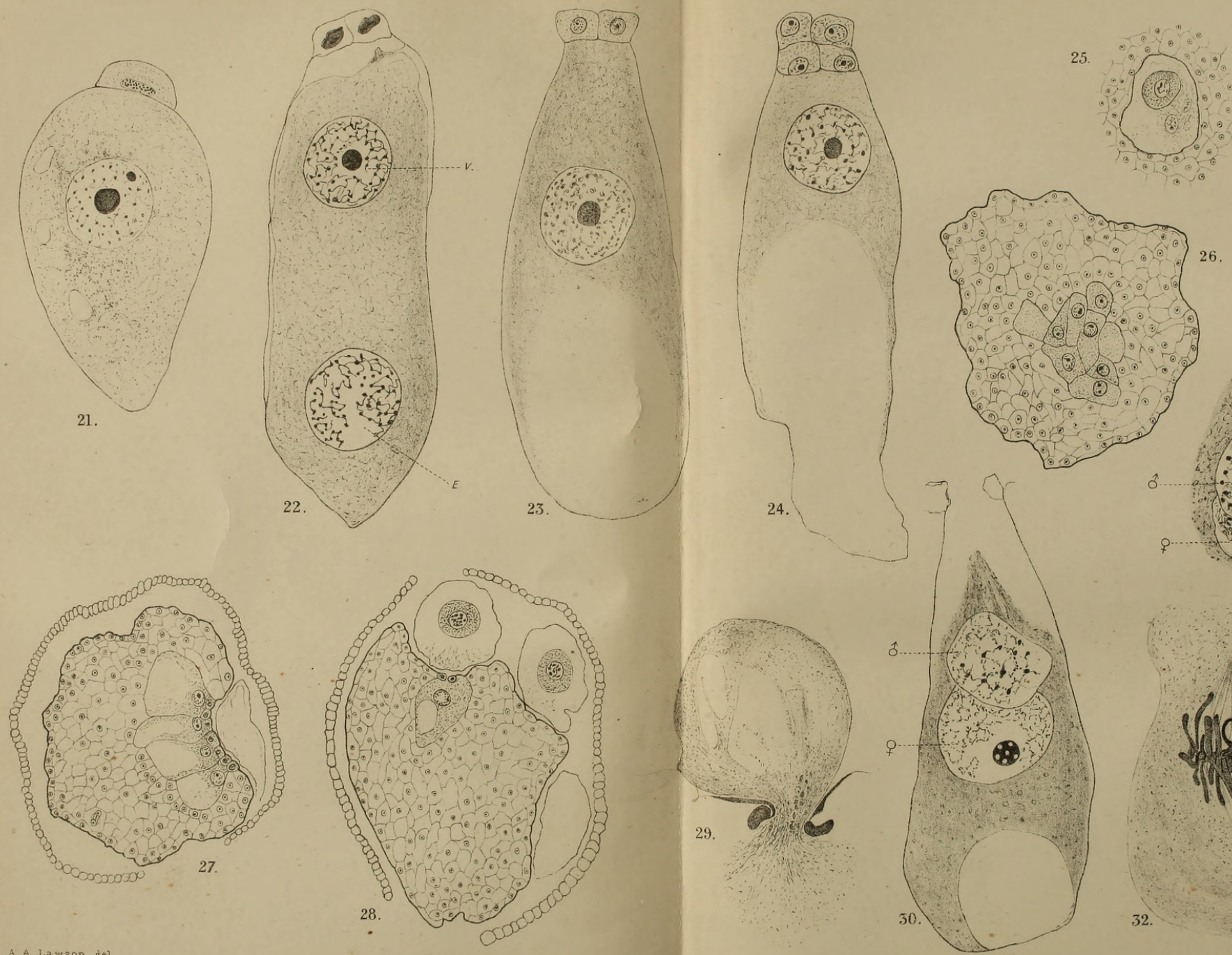

29.
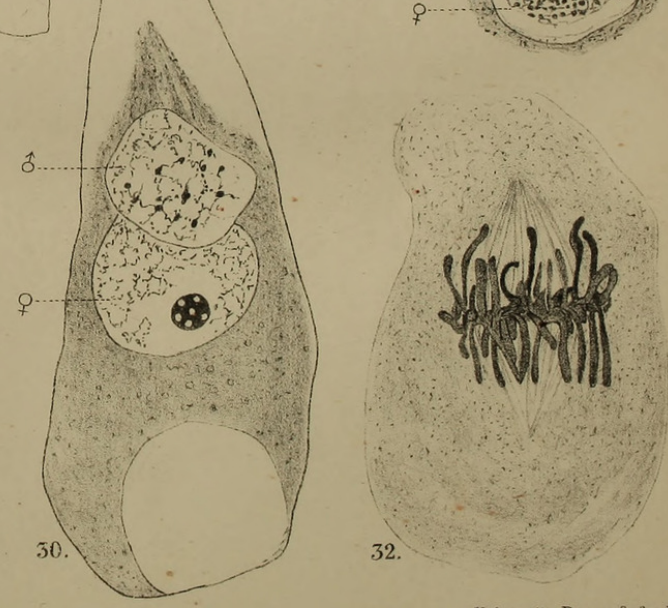

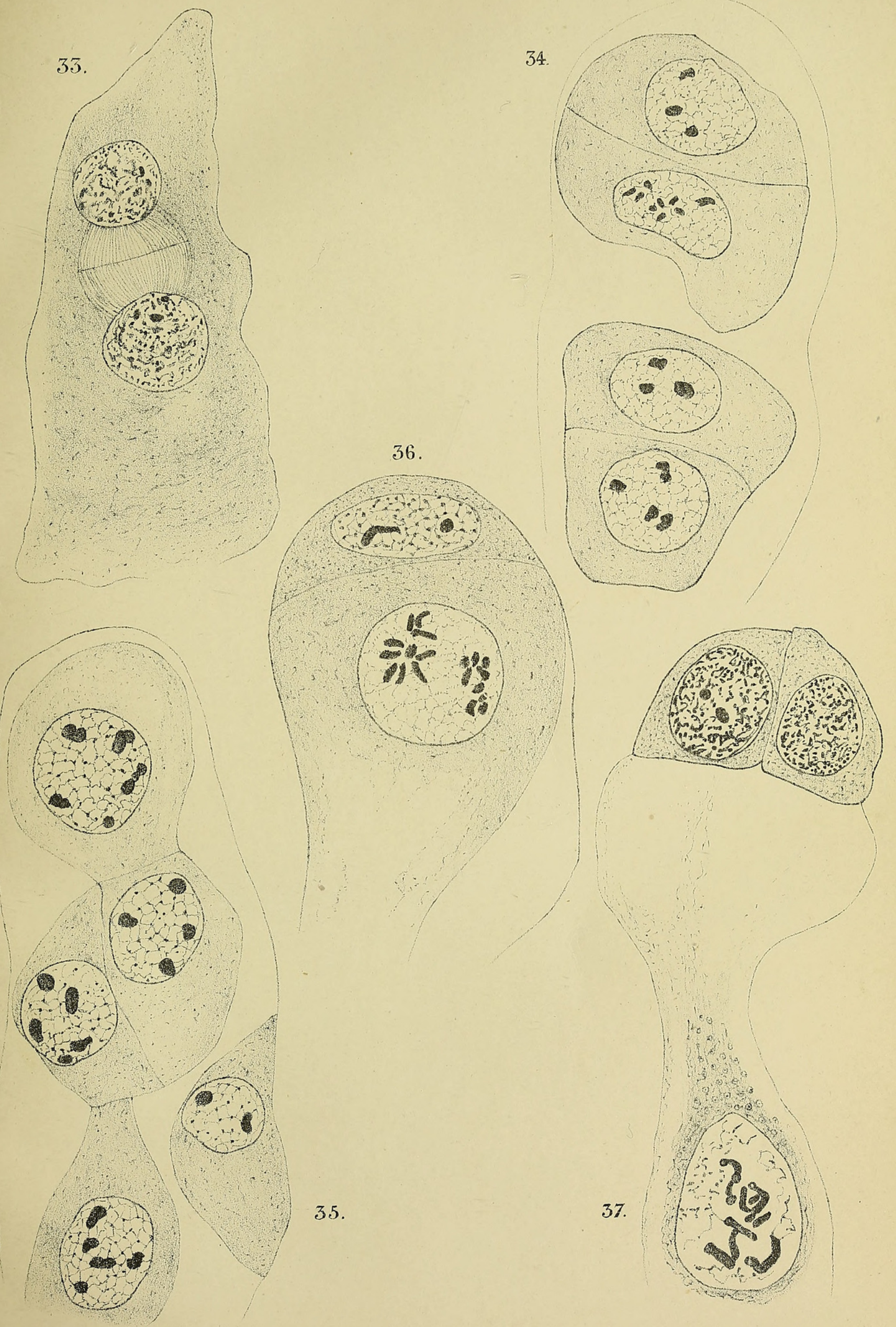


\section{$2 \mathrm{BHL}$ Biodiversity Heritage Library}

Lawson, Abercrombie Anstruther. 1904. "The gametophytes, archegonia, fertilization, and embryo of Sequoia sempervirens." Annals of botany 18, 1-28. https://doi.org/10.1093/oxfordjournals.aob.a088946.

View This Item Online: https://www.biodiversitylibrary.org/item/234469

DOI: https://doi.org/10.1093/oxfordjournals.aob.a088946

Permalink: https://www.biodiversitylibrary.org/partpdf/318744

\section{Holding Institution}

Smithsonian Libraries

\section{Sponsored by}

Biodiversity Heritage Library

\section{Copyright \& Reuse}

Copyright Status: Not in copyright. The BHL knows of no copyright restrictions on this item.

This document was created from content at the Biodiversity Heritage Library, the world's largest open access digital library for biodiversity literature and archives. Visit BHL at https://www.biodiversitylibrary.org. 